\title{
Animal Law in South Africa: "Until the lions have their own lawyers, the law will continue to protect the hunter"
}

\author{
Amy P. Wilson \\ Attorney. LL.M Animal Law Lewis \& Clark Law School in Portland, USA \\ Director and Co-founder Animal Law Reform South Africa
}

Received: December 2018

Accepted: January 2019

Recommended citation. WILSON A.P., Animal Law in South Africa: "Until the lions have their own lawyers, the law will continue to protect the hunter"dA. Derecho Animal (Forum of Animal Law Studies) 10/1 (2019) - DOI https://doi.org/10.5565/rev/da.399

\begin{abstract}
Despite the importance of animals to South Africa, animal law is not yet recognized a separate distinct area of law. In an attempt to rectify this, the article provides a high level introduction to this highly complex field. By providing background and context into historical and current injustices regarding humans and animals, it alleges that the current legal system has failed to provide adequate protection to either group. By analyzing the existing regulatory framework and case law, it lays out the realities of obtaining better protection for animals in law. It then argues why it is particularly critical for the country to consider animal interests both individually and collectively with human interests by providing examples of how these interests intersect in practice. It suggests an approach for future protection efforts and concludes by providing some opportunities going forward for animal law reform in South Africa.
\end{abstract}

Keywords: Animal law; South Africa; animals; animal protection; law; human rights.

Resumen - Derecho Animal en Sudáfrica: "Hasta que los leones no tengan sus propios abogados, la ley seguirá protegiendo al cazador"

A pesar de la importancia de los animales para Sudáfrica, el derecho animal aún no es reconocido como un área distinta dentro del Derecho. En un intento por rectificar esto, el artículo proporciona una introducción de alto nivel a este campo tan complejo. Proporcionando antecedentes y un contexto a las injusticias históricas y actuales en relación a los humanos y animales, se alega que el sistema jurídico actual no proporciona una protección adecuada a ninguno de los grupos. Analizando el marco regulatorio y la jurisprudencia existente, se establecen las realidades de la obtención de una mejor protección para los animales en el Derecho. A continuación argumenta por qué es particularmente crítico para el país tener en consideración los intereses de los animales de forma tanto individual como colectiva con los intereses humanos proporcionando ejemplos de cómo dichos intereses se cruzan en la práctica. Sugiere un enfoque para futuros esfuerzos de protección y concluye brindando algunas oportunidades para la reforma del derecho animal en Sudáfrica.

Palabras clave: derecho animal; Sudáfrica; animales; protección animal; Derecho; derechos humanos.

1 "Until the lions have their own historians, the history of the hunt will always glorify the hunter." - African Proverb. 


\author{
"We, the people of South Africa, \\ Recognise the injustices of our past; \\ Honour those who suffered for justice and freedom in our land; \\ Respect those who have worked to build and develop our country; and \\ Believe that South Africa belongs to all who live in it, united in our diversity" ${ }^{2}$
}

\title{
Introduction
}

If one mentions "animal law" in South Africa, the common response is one of confusion turned to interest. This is due to the fact that it is not yet a recognized, distinct field of law as it is in other jurisdictions around the world. ${ }^{3}$ Some may view this as surprising, considering that the importance of animals to South Africa as a nation and its people, cannot be overstated.

In fact, to many, South Africa is the hub of animal experiences, hosting some of the largest populations of charismatic megafauna ${ }^{4}$ and ranking the third most biodiverse country in the world. ${ }^{5}$

However, the relationship with our fellow animals is a confounding one. Quintessential African species such as lions, elephants, rhinos are hunted for trophies, offered in human interactions, and both live animals and their body parts are lawfully traded locally and internationally. ${ }^{6}$ These and other wild animals are kept in zoos, used in circuses and aquaria, and otherwise exploited in the tourism industry or dealt with in abundant other consumptive and non-consumptive ways.

Millions upon millions of animals are farmed and killed to meet the growing demand for animal protein, ${ }^{7}$ with abhorrent practices such as veal crates, sow stalls and battery cages widely utilized. If these animals are not kept alive as breeding machines they are slaughtered, and their body parts are wrapped up for store shelves - ready for guilt-free human consumption. Live animals are shipped across the oceans under conditions where they suffer terribly, over long periods of time. Animals are killed in cultural and religious ceremonies with ritual slaughter commonplace (with certain exemptions granted for these practices). Animal research and testing occurs largely unregulated ${ }^{8}$ and there is no prohibition on testing on animals for cosmetic purposes. Working animals face their own varied threats. ${ }^{9}$

Most of the practices in relation to animals occur largely behind closed doors with little transparency and accountability, sanctioned by the government. The public at large unwittingly supports the success of these industries by perpetuating the demand and thus ensuring the continuation of one of the largest injustices of our time.

\footnotetext{
2 Preamble to the Constitution of the Republic of South Africa, 1996 (referred to as the Constitution). Government Website: http://www.justice.gov.za/legislation/constitution/SAConstitution-web-eng.pdf [Last Consultation Date: 16 December 2018]

${ }^{3}$ This is not to say that lawyers may not be practicing in this field - it is not yet however known distinctly on its own. While animal law as a field considers the interests of the animal itself, usually, in the South African context, animals are considered generally in the context of another area. Thus, for example, animal interests may arise in the area of environmental law. Environmental lawyers, environmental focused non-profits and environmental departments in law firms all exist and are well-established, yet the same cannot be said for animal law. Other examples indicating that this is not yet a distinct field, are a lack of use of the term "animal lawyer" (although I regard myself as one); absence of courses on the subject in Universities, and others. For the purposes of this Article, when referring to "animal law" I mean generally as a distinct field.

${ }^{4}$ South Africa is host to the largest population of rhino and ostriches in the world. It also has "large" elephant and lion populations. Notably however, for rhinos, lions and ostriches, this is due to their intensive farming.

${ }^{5}$ According to the Biodiversity Finance Initiative Website: https://www.biodiversityfinance.net/south-africa [Last Consultation Date: December 132018$]$

${ }^{6}$ Despite the gravity of the illegal trade in wildlife and their parts a detailed discussion falls outside the scope of this Article.

${ }^{7}$ With approximately one billion chickens killed every year (chickens forming about $60 \%$ of the animal protein demand), 3,5 million cattle for beef, 3 million pigs for pork and collectively 5 million for sheep and lamb. Department of Agriculture, Forestries and Fisheries

Website: https://www.daff.gov.za/Daffweb3/Portals/0/Statistics\%20and\%20Economic\%20Analysis/Statistical\%20Information/Abstract\%202 018.pdf). [Last Consultation Date: December 11 2018].

This excludes the millions of fish, the growing aquaculture industry and "Operation Phakisa".

${ }^{8}$ Recent efforts have included updating non-binding, voluntary standard by the South African Bureau of Standards. These are not legally enforceable but have persuasive value. Other than this, there is little regulation and oversight as to the treatment of animals used in vivisection in South Africa, in terms of animal welfare.

${ }^{9}$ One example for donkeys is the increasing demand for their hides in certain Asian countries for the making of "ejiao", a gelatin consumed in Asian countries for medicinal purposes. Donkeys in South Africa face major threats from this practice.
} 
As is apparent, the significance of animals and the policies and legal protection offered to them create a dichotomy. ${ }^{10}$ Although this is not unique to South Africa, nor is it uncommon for moral considerations and the law to be different, the particular history of the country and prevailing circumstances should impose a greater obligation to address oppression, regardless of the oppressee, or the rationale for the oppression.

At the outset I wish to note that I am of the view that animals have their own intrinsic worth as individuals and have an interest in having that worth protected. They should therefore receive such protection in their own right and for reasons that flow from that worth. I accept this as a fundamental truth and affirm it throughout. ${ }^{11}$ Following on from this, such protection must out of necessity be recorded in statute and law in order to be enforceable. ${ }^{12}$

With this article I attempt to provide a rudimentary introduction to the highly complex field of animal law in South Africa. I will start by providing some necessary background and context and then analyze the current regulatory framework both on paper and in practice. I will then argue why it is particularly critical for the country to consider animal interests both individually and collectively with human interests by providing examples of how they intersect. I conclude by providing some suggestions and opportunities for animal law reform.

Due to the diversity of this topic and my attempt to offer an understanding of the many factors that come into play, I am unable to explore specific considerations in depth (particularly some that warrant further explanation); however, I hope to expand on these as I continue to learn more about this field. I further hope that it may be useful to others, or at least create a platform for debate. On this note, as an attorney and not a philosopher, I have tried to minimize the theoretical aspects and focus more on the practical application of the field. My experience, although burgeoning, has revealed an obligation to consolidate information and my learnings and set a basis for future efforts. I have no doubt that these efforts will continue to grow and gain emphasis, as the animal protection and animal law movements have done globally.

\section{Background and Context}

Apartheid (literally translated meaning "separateness") was the system of racial segregation and discrimination that forced different racial groups to live separately, use different facilities and otherwise develop severally. ${ }^{13}$ Separate was not, however, designed to create a system of equality, but to entrench the idea of white supremacy ("baaskaap") and emphasize the difference between peoples based on the colour of their skin.

Not only did this system separate whites from other racial groups, it also divided racial groups themselves. Despite its tyranny, this ideology was entrenched in the legal system by the Nationalist Government passing and implementing oppressive laws for nearly half a century. ${ }^{14}$ Laws ranged from prohibiting sexual relationships between white people and people of other races to forcing black people to live in specific homelands and away from white people, except as a labor force. ${ }^{15}$

\footnotetext{
${ }^{10}$ Except when the context indicates otherwise, I have not specified environment as a separate consideration nor environmental law considerations herein. This is not because same is not a vital consideration in the discussion, particularly one about following an integrated approach and considering all stakeholder given the recent movements for "earth" rights, "nature rights" and the like. The rational for doing this is not based on the environment not being worthy of consideration, but rather due to the fact that animal law issues have traditionally been grouped under this umbrella, and for the purposes of this article I wish to give animal law and the field its own identity as separate and distinct from environmental law, as well as integrated with it. Accordingly, by referencing animals and humans only when nature's interests are affected, this is not meant to be exclusionary, but rather contextual.

${ }^{11}$ There is no shortage of material or literature setting out ethical and moral considerations of animals or why they should be protected. There is no lack of scientific evidence of the fact that animals can suffer nor their sentience.

${ }^{12}$ David Bilchitz has written extensively on the subject of animals and the law in South Africa. I will reference him and his work throughout as one of the pioneers in the subject matter. Bilchitz argues convincingly that traditional classification of animals cannot withstand scrutiny, excluding them is essentially arbitrary and that the existing constitutional and common law can be interpreted to recognize legal personhood for non-human animals, but is unsure of whether South African society is ready to embrace the full implications of this recognition: See: BILCHITZ, D. Moving Beyond Arbitrariness: The Legal Personhood and Dignity of NonHuman Animals South African Journal on Human Rights 25 (2009) 38-72 (https://doi.org/10.1080/19962126.2009.11865192). [Last Consultation Date: December 102018$]$.

${ }^{13}$ For further information on the crime of apartheid, I refer to the United Nation's International Convention on the Suppression and Punishment of the Crime of Apartheid. Adopted by the General Assembly of the United Nations on 30 November 1973. Website: https://reaties.un.org/doc/Publication/UNTS/Volume\%201015/volume-1015-I-14861-English.pdf [Last Consultation Date: December 142018$]$

${ }^{14}$ This subject has been written on substantially and will not be expanded on here.

${ }^{15}$ Examples include the Prohibition of Mixed Marriages Act 55 of 1949, Natives Laws Amendment Act of 1952 and various others. University of KwaZulu-Natal Website: http://scnc.ukzn.ac.za/doc/HIST/Apartheid\%20Legislation\%20in\%20South\%20Africa.htm [Last Consultation Date: December 132018$].$
} 
Interestingly, while the government was passing and implementing laws systematically to discriminate against certain groups, it also passed the primary law regulating animal protection still utilized today. ${ }^{16}$

In 1994, the country formally became a democratic state and later adopted the Constitution. Whilst the document attempted to address discrimination and oppression on multiple grounds relating to humans, animal interests were not considered.

Since then, various attempts have been made to "decolonize" sectors and aspects of South African society, yet, as a nation, it continues to base its relationship on legal concepts and principles that arrived in the country with the colonizers nearly four centuries ago, concepts based on Roman-Dutch law and English law. Oppressive principles such as the categorization of animals as things have become further entrenched through social norms, desensitization, euphemistic terms, ${ }^{17}$ and vested economic and other interests.

Today, the Republic's population of over 56 million people is referred to as the 'rainbow nation', united in its diversity of cultures, races, languages, religious and other beliefs. Notwithstanding the vast strides in addressing prejudices of the past with its world-class Constitution promising fundamental rights to all ${ }^{18}$ and non-discrimination, ${ }^{19}$ "separateness" is still evidenced by social, economic and other circumstances. Poverty, unemployment, violence, crime and inaccessibility to food, water and education are daily realities for the large majority. With limited resources to combat these, many question how as a nation, we can even contemplate animal protection efforts with so much human suffering. I offer that we can only begin to combat human suffering by also considering animals' interests, as human and animal interests are fundamentally linked. Up until now, the law has failed to recognize this, although we are starting to see some progress in this regard. ${ }^{20}$

\section{Status Quo: Legal System and Regulatory Framework}

\section{Legal System}

By way of brief background, South Africa has a mixed legal system composed of Roman-Dutch law (civil) and English (common law) elements. ${ }^{21}$ Additionally, there is customary law, which is constitutionally recognized as a legal system that should run alongside and in parity for the aforementioned legal system meaning that there is legal pluralism. ${ }^{22}$ Although both the common and civil law have been significantly modified by the passing of statutes and interpretation and modification by the judiciary respectively, many of the underlying principles still permeate the law today, with differing scope and impact. The Roman law of property, for example, largely influenced this area in South Africa's own legal system and thus began the formal recognition of animals as "things" or "res" in law. ${ }^{23}$

This categorization, not dissimilar to others in legal systems around the world, separates animals from legal persons or rights-bearers, excluding them from the rights, protections and other benefits such status provides. ${ }^{24}$ This effectively excludes them as stakeholders and ensures their interests are not properly accounted for in the legal system. Although restrictions do exist as to how they may be treated, this status

\footnotetext{
${ }^{16}$ Aside from the Environmental laws adopted under the new dispensation, dealt with in further detail in the next section.

${ }^{17}$ Such as "pork" and "beef" (not pigs or cows) "culling", "destroying" and "harvesting" (not killing); "game" (not wild animals); "resources" (and not animals) and referencing animals as "damage causing" as justification for less legal protection. It is no wonder then that the term "sustainable use" has become synonymous with abuses used to justify policy and decision making.

18 All persons, animals are not included.

${ }^{19}$ On the basis of inter alia race, gender, sex, pregnancy, marital status, ethnic or social origin, colour, sexual orientation, age, disability, religion, conscience, belief, culture, language and birth. Section 9 of the Constitution.

${ }^{20}$ This principle is included in various International Law and domestic law instruments whether directly or indirectly.

${ }^{21}$ For further information and history on the South African legal system, please see: Supreme Court of South Africa: Website: http://www.justice.gov.za/sca/historysca.htm [Last Consultation Date: December 11 2018].

${ }^{22}$ Customary law is the law of the indigenous peoples of South Africa. The area of customary law and animal protection warrants further exploration, particularly in relation to conflicting interests. For a practical example of the conflict of Customary law and women's rights, see SA History Website: https://www.sahistory.org.za/article/customary-law-south-africa-historical-developmentlegal-system-and-its-relation-women $\%$ E2\%80\%99s-righ [Last Consultation Date December, 10 2018]. Customary law has also been formally adopted into legislation, such as the Recognition of Customary Marriages Act 120 of 1998. Government Website: http://www.justice.gov.za/legislation/acts/1998-120.pdf [Last Consultation Date: December 10 2018].

${ }^{23}$ Except instead of being uncodified - this notion has now been formally and explicitly included in different pieces of legislation Including but not limited to the Performing Animal Protection Act 1935 as amended and the Game Theft Act 105 of 1991 , in relation to "game" ownership. South African Police Services Website: https://www.saps.gov.za/resource centre/acts/downloads/juta/news1334.pdf [Last Consultation Date: December 102018 ].

${ }^{24}$ Bilchitz argues the arbitrariness of excluding animals from the law by exploring the concept of "person" and "dignity" and concludes that there is no acceptable justification for recognizing that worth only resides in human beings and, consequently, that only human beings are capable of having rights that must be respected: Supra Bilchitz note 12 at 66 .
} 
ultimately forms the basis of the laws relating to and affecting them.

The new constitutional dispensation, however, requires us to rethink this approach by mandating that when judicial bodies are interpreting any legislation or developing common or customary law, they must promote the spirit, purport and objects of the Bill of Rights. ${ }^{25}$

\section{Regulatory Framework}

Despite the failure of animal law to yet be recognized as a legitimate field, there is no scarcity of law or regulation relating to or affecting animals - however undesirable or unsuccessful at taking into account their interests these are. Navigating the regulatory landscape can lead one on quite an adventure, depending on the species, use, "value" or allocated importance of the animal. The plethora of regulation is composed of the Constitution (supreme law), national law s, provincial laws, local laws, soft laws and private arrangements. This regulation is inadequate at offering animals the protections they deserve. Their content and implementation have led to loopholes, inconsistencies, uncertainty and enforcement challenges with detrimental impacts.

There are, of course, some positive aspects within the existing framework that can be utilized in future efforts - many we have yet to take full advantage of - but achieving these in practice will undoubtedly prove challenging.

In an attempt to simplify the South African legal system as it relates to animals, I shall follow a hierarchical approach as far as possible. At the top of the framework is the Constitution of the Republic of South Africa.

The final Constitution, referred to as the "birth certificate" 26 of democracy, was adopted in 1996 and is often praised as one of the best in the world in terms of the scope of rights and protections offered. It is the supreme law of the Republic and as such no other law may conflict with it; nor may the government do anything that violates it. These principles are upheld by the Constitutional Court, the highest court on constitutional matters. The Bill of Rights contained in Chapter Two is a cornerstone of democracy which enshrines the rights of all people and affirms the democratic values of human dignity, equality and freedom.

Seemingly, then, if something is important, it is in the Constitution. However, animals are not expressly mentioned in the Bill of Rights at all, and they are only included in the Schedules of the main text, establishing which level of government has authority to deal with regulating them. ${ }^{27}$ National and provincial government have concurrent legislative competence over the functional areas of animal control and diseases, agriculture, environment, and nature conservation. ${ }^{28}$ Provinces have exclusive jurisdiction over abattoirs and veterinary services, excluding regulation of the profession. Local government has jurisdiction over issues of facilities for the accommodation, care and burial of animals, licensing of dogs, municipal abattoirs, pounds, and control of public nuisances.

A constitutional provision that has been confirmed to include animal's interests, ${ }^{29}$ albeit not in the express wording, is the right to environment. ${ }^{30}$ This right includes, among other things, the right to have the environment protected through measures that "promote conservation" and "secure ecologically sustainable development and use of natural resources while promoting justifiable economic and social development". Whilst this provision, in fact, can be seen to be rather complex, the sustainable use policy adopted by government in relation to wild animals that underpins many of its environmental and biodiversity policies. This concept has been used to justify controversial and cruel practices in the name of conservation, both to individual and groups of wild animals, while not having to account for their interests or protection.

The Constitutional Court, however, has indicated that the intrinsic worth of animals must be protected. It has refused to interpret environmental protection separately from animal welfare and indicated that the two are intertwined values. ${ }^{31}$ This ideology is based on the integrative approach, ${ }^{32}$ which the court

\footnotetext{
${ }^{25}$ Section 39(2) of the Constitution.

${ }^{26}$ Constitutional Court of South Africa Website: https://www.concourt.org.za/index.php/constitution/what-is-a-constitution. [Last Consultation Date: December 1020181.

${ }^{27}$ Contained in Schedules 4 and 5 respectively.

${ }^{28}$ Note that aside from specific carve outs provided for, national legislation would generally prevail over provincial legislation in the event of conflict.

${ }^{29}$ BILCHITZ D. Exploring the Relationship between the Environmental Right in the South African Constitution and Protection for the Interests of Animals South African Law Journal 34 (2017) 740 - 777. (http://dx.doi.org/10.2139/ssrn.2942112). [Last Consultation Date: December 102018$]$

${ }^{30}$ Section 24: "Everyone has the right- (a) to an environment that is not harmful to their health or wellbeing; and (b) to have the environment protected, for the benefit of present and future generations, through reasonable legislative and other measures that - (i) prevent pollution and ecological degradation; (ii) promote conservation; and (iii) secure ecologically sustainable development and use of natural resources while promoting justifiable economic and social development."

${ }^{31}$ National Society for the Prevention of Cruelty to Animals v Minister of Justice and Constitutional Development and Another
} 
said correctly links the suffering of individual animals to conservation and illustrates the extent to which showing respect and concern for individual animals reinforces broader environmental protection efforts.

Although the above statements by the court relate to wildlife policies, a similar approach may be applied to animals more generally, given their own value and interests, together with human interests. This affirmation by the country's highest court in interpreting the supreme law is profoundly significant for animals. It asserts that in considering their individual interests and suffering, it fortifies protection of human interests.

Moving on from the Constitution, at a national level ${ }^{33}$ there are two categories of laws relating to animals that will be discussed - the first category is "animal-welfare/centric" type laws and the second is "environment-centric" laws.

In the first category, I wish to highlight three main laws that could be considered protective of animals: the Animal Protection Act (APA), ${ }^{34}$ the Performing Animals Protection Act (PAPA), ${ }^{35}$ and the National Society for the Prevention of Cruelty to Animals Act (SPCA Act). ${ }^{36}$

The primary animal protection statute is from $1962,{ }^{37}$ and although it has been amended during its 57 -year reign, ${ }^{38}$ it has not substantially changed the situation for animals. It offers protection to most categories of animals, including farm animals, ${ }^{39}$ but fails to include all animals in its ambit such as fish and wild animals not in captivity, i.e. in their natural state. ${ }^{40}$ One of the main consequences of this is that wild animals in the "wild "are not subject to the same protections as other animals, and are instead regulated by environmental legislation - generally emphasizing biodiversity. These environmental laws fall under the jurisdiction of an entirely different government department that argues it is not mandated to deal with the "issue" of welfare. ${ }^{41}$

This law is wide in terms of the unlawful actions covered and includes both negligent and intentional acts that could be widely interpreted. Some examples include but are not limited to overloading, overdriving, overriding, ill-treating, neglecting, infuriating, torturing or maiming, cruelly beating, kicking, goading or terrifying any animal. ${ }^{42}$ It is for this reason perhaps that some, such as the National Society for the Prevention of Cruelty to Animals (NSPCA), have indicated that, although they believe the act is in need of a total overhaul with regard to various offenses, the act is generally "a sound piece of legislation which compares well on a global scale". ${ }^{43}$

However "broad" the definition and list of offenses may be, problematic provisions exist. One principal example is the reference throughout the Act to acts that cause "unnecessary suffering" being unlawful. ${ }^{44}$ Despite the term being unclear (i.e. what might necessary suffering be), it places the onus of

(CCT1/16) [2016] ZACC 46; 2017 (1) SACR 284 (CC); 2017 (4) BCLR 517 (CC) (8 December 2016). Saflii Website: http://www.saflii.org/za/cases/ZACC/2016/46.html\# ftn91 Last Consultation Date: December 1020181.

32 Supra Bilchitz, note 30.

${ }^{33}$ There are various other laws that affect animals but these fall outside the ambit of this discussion. The Department of Agriculture, Forestries and Fisheries (government department tasked with welfare) sets out some of the legislation within its responsibility, many of which relate to animals directly and indirectly. See Department of Agriculture, Forestries and Fisheries Website: https://www.daff.gov.za/doadev/sidemenu/links/legislation.htm). [Last Consultation Date: December 13 2018]. Notably this list contains repealed laws no longer in force. It also indicates that new legislation has not been passed by the Department in 18 years.

${ }^{34}$ Animal Protection Act 71 of 1962 as amended. Animal Law Info Website:

https://www.animallaw.info/sites/default/files/AnimalsProtectionAct71-62.pdf [Last Consultation Date: December 102018$].$

35 The Performing Animals Protection Act 24 of 1935. Government Website: https://www.gov.za/documents/performing-animalsprotection-amendment-act-4-2016-english-afrikaans-19-jan-2017-0000 [Last Consultation Date: December 102018 ].

${ }^{36}$ Societies for the Prevention of Cruelty to Animals Act 169 of 1993. Saflii Website: http://www.saflii.org/za/legis/num act/sftpoctaa1993521/. [Last Consultation Date: December 142018$]$

37 It replaced the previous animal protection law, the Prevention of Cruelty to Animals Act 8 of 1914.

${ }^{38}$ Including an amendment in terms of the Animal Matters Amendment Act 42 of 1993 regarding the prohibition on animal fighting.

39 "Animals" means any equine, bovine, sheep, goat, pig, fowl, ostrich, dog, cat, or other domestic animal or bird, or any wild animal, wild bird or reptile which is in captivity or under control of any person.

40 The most recent attempt to amend this Act was in November 2017, in terms of a private member's bill (in terms of which a member of Parliament was lobbied by Beauty Without Cruelty to introduce a ban on the testing of cosmetics). The amendment did contain some other positive provisions such as removing the words "destruction" and "destroy" and increased penalties but has not yet been passed into law. The original proposed draft was meant to include a ban on the use of animals in circuses, but notably this was not provided for in the draft being considered by Parliament.

${ }^{41}$ An excellent analysis on the laws relating to wildlife and the challenges associated therewith has been done for the Center for Environmental Rights \& Endangered Wildlife Trust: Fair Game. CER Website: https://cer.org.za/wp-content/uploads/2018/06/CEREWT-Regulation-of-Wildlife-Welfare-Report-25-June-2018.pdf. [Last Consultation Date: December 13 2018].

${ }^{42}$ For a full list, see section 2(1)(b) of the Animal Protection Act.

${ }^{43}$ For further information, see NSPCA Website: https://nspca.co.za/wp-content/uploads/2016/05/Animal-Protections.pdfv). [Last Consultation Date: December 12 2018]. Problematically, this source indicates that "The definition of an "animal" in the Act covers ALL animals" which is not accurate.

${ }^{44}$ Bilchitz discusses this in detail in his work: BILCHITZ D. When is Animal Suffering Necessary? (2012) Southern African Public Law, 27 (2012) 3-27 (https://journals.co.za/content/sapr1/27/1/EJC153188). [Last Consultation Date: December 122018$].$

40 Derecho Animal. Forum of Animal Law Studies, vol. 10/1 
proof on the person alleging cruelty. Other criticisms include the fact that additional confusing terms and inconsistencies exist, such as "cruelly beating" - again, what might "uncruel" beating be - and that the penalties and punishment provided for cruelty are insufficient.

The Act also empowers the Minister of Justice to make regulations relating to sundry matters on animals ${ }^{45}$ although this is not mandatory, and the Minister has yet to promulgate appropriate regulations in this regard. It is supposedly for this reason that animal-use industries have turned to self-regulation or regulation through the South African Bureau of Standards (SABS) ${ }^{46}$ including in areas of animal research and testing and certain aspects of animal agriculture and transport.

Aside from the content of the Act, further problems exist with its enforcement. In addition to the South African Police Services (SAPS) and prosecutors, the act is enforced by the NSPCA. It provides for wide powers for officers of any SPCA,${ }^{47}$ if authorized by a magistrate, to enter and inspect premises, make arrests, and seize animals. In a recent victory the Constitutional Court affirmed the right of the NSPCA to bring private prosecutions ${ }^{48}$ and it has been prosecuting numerous animal cruelty cases with varying success, along with numerous other efforts in this arena. However, reports indicate that even though the NSPCA has laid charges against workers at battery hen and abattoir operations for cruelty to farmed animals, these have not ever made it to prosecution, let alone conviction. ${ }^{49}$

The second piece of national legislation is the 84-year-old Protection of Performing Animals Act, which, despite its name, offers little protection to performing animals. It mostly regulates the issuing of licenses and fails to (among other things) prohibit cruel training methods for animals used in entertainment and the regulated industries. It includes the same animals in its ambit as the APA, and therefore the same exclusions. A 2013 challenge to the act by the NSPCA $^{50}$ saw two of its provisions being declared unconstitutional by the Constitutional Court, although the reasons provided therefore have been rightly criticized, including the fact that animal's interests were not taken into account at all. ${ }^{51}$ The legislature was ordered to amend the 1935 act and a few more protective provisions, such as the requirement for the applicant seeking a license in terms of the act to provide information pertaining to the animal and its requirements.

Although the core issue of the aforementioned case related ultimately to the separation of powers doctrine between the executive and judiciary, it was significant as it was the first time animal welfare legislation was considered by the Constitutional Court and under the new constitutional dispensation. The court, however, ultimately failed to engage in core principles and equated the issuing of licenses for animals used in performances to issuing licenses to sell liquor and for gambling. Notably, this case was prior to the aforementioned case where the same court adopted the integrative approach, thus rectifying the error of failing to consider animal interests.

The final statute in this category is the Society for the Prevention of Cruelty to Animals Act. The Act mostly provides for administrative matters that relate to the individual societies for the prevention of cruelty to animals and the national body in charge of controlling these, the National Society for the Prevention of Cruelty to Animals (NSPCA). It includes the express provisions that the object of the NSPCA is to "prevent the ill-treatment of animals by promoting their good treatment by man", thus providing evidence of animal's interests being counted in their own right and their need for a representative body to ensure these. The importance of the role of the NSPCA has been emphasized by the courts in various cases. $^{52}$

\footnotetext{
${ }^{45}$ Such as those that would regulate the method and form of confinement and accommodations for any animal or class, species or variety of animals, whether travelling or stationary, and any other reasonable requirements which may be necessary to prevent cruelty to or suffering of any animal.

${ }^{46}$ SABS is a statutory body that was established in terms of the Standards Act 24 of 1945, that essentially releases standards for quality purposes.

${ }^{47}$ Individual societies for the prevention of cruelty to animals.

${ }^{48}$ Supra, NSPCA Case note 32. The case was brought by the NSPCA as the prosecutors failed to bring a case against those involved a religious sacrificial slaughter of two camels alleged by the NSPCA to be in contravention of the Animal Protection Act.

${ }^{49}$ Supra, Center for Environmental Rights \& Endangered Wildlife Trust, note 42.

${ }^{50}$ Minister of Agriculture, Forestry and Fisheries v National Society for the Prevention of Cruelty to Animals (CCT186/16) [2016] ZACC 26; 2016 (11) BCLR 1419 (CC) (25 August 2016). Saflii Website: http://www.saflii.org/za/cases/ZACC/2016/26.html [Last Consultation Date: December 13 2018].

${ }^{51}$ BILCHITZ D. What was Left Unsaid: The Unconstitutionality of the Performing Animals Protect Act in NSPCA v Minister of Agriculture, Forestry and Fisheries' South African Journal on Human Rights, 30 (2014) (https://hdl.handle.net/10520/EJC153000) [Last Consultation Date: December 14 2018].

52 In the Openshaw Case, Cameron JA emphasised that the NSPCA is "a public body with wide and singular responsibilities in the field" and that the singularity of the NSPCA's position is armoured by the fact that it is tasked with "preventing ill-treatment of voiceless beings". Cameron further stated in a minority judgement that animals are worthy of protection not only because of the reflection that this has on human values, but because animals "are sentient beings that are capable of suffering and of experiencing pain. See National Council of Societies for the Prevention of Cruelty to Animals v Openshaw (462/07) [2008] ZASCA 78; [2008] 4
} 
The remainder of legislation as managed by the Department of Agriculture, Forestries and Fisheries (DAFF) align with the current human-centric approach to animals, such as the Meat Safety Act. Although it provides that an animal presented for slaughter at an abattoir must be handled "humanely" during loading, transportation, off-loading, housing, immobilizing and killing, records that its purpose is to promote meat safety and the safety of animal products. ${ }^{53}$ Other laws deal with animal health, diseases and identification and are not dealt with further herein.

The second category of national laws affecting animals that will be dealt with herein are those regulating environmental issues and the like as managed by the Department of Environmental Affairs (DEA). ${ }^{54}$ These include the "umbrella" act, National Environmental Management Act (NEMA), ${ }^{55}$ and specific environmental management acts (SEMAs) such as the National Environmental Management: Biodiversity Act (NEMBA), which regulates biodiversity. ${ }^{56} \mathrm{~A}$ web of regulations have been promulgated under NEMBA by the Minister of Environmental Affairs, ${ }^{57}$ such as those relating to Threatened or Protected Species (TOPS), ${ }^{58}$ as one example.

To add another layer of regulation, we have "Policies" and "Norms and Standards". Most notable are those relating to the management of elephants. ${ }^{59}$ These, in some instances, provide more progressive recordals and provisions than most other legislation, such as the explicit recognition of elephants' sentient nature, intelligence and highly organized social structure. Yet, the same document still allows for processes such as trophy hunting and culling and fail to prohibit other certain abuses of elephants, such as their use in circuses or for safari back riding. ${ }^{60}$

The next level of regulation is that of provincial law, ${ }^{61}$ with South Africa having nine recognized provinces. Provincial legislation is not uniform and differs from one province to the other. As aforementioned, because provinces have concurrent jurisdiction over certain matters, regulation can be different both between provinces themselves and between provinces and national government. A practical example of a drawback with this framework is the issuing of permits for activities relating to wildlife including but not limited to hunting, catching, capturing or killing, growing, breeding or propagating. The lack of consistency of legislation, no national database of permits and little transparency and co-ordination between the provinces, has left legal loopholes that have had a detrimental impact on wildlife. ${ }^{62}$

The final relevant level of governmental regulation is local laws or bylaws that regulate matters within the jurisdiction of a city council. They deal with issues involving the licensing of animals, companion animals, nuisance, and other issues within their jurisdiction.

Also operating within this framework are "soft" laws, such as voluntary industry standards. These have arisen due to failure by the government to promulgate specific regulation on certain matters pertaining to animals, their use and incidental matters. These are compiled by SABS in consultation with industry. Although the standards are non-binding, they cover a broad variety of issues across sectors - and are thus persuasive. In relation to animals, for example, standards relate to 'Humane transportation of livestock by road', 'Welfare of wild animals transported by sea' and 'Translocation of certain species of wild herbivore', to name a few. Aside from the non-binding nature of these and the lack of sanction for non-compliance, ${ }^{63}$

All SA 225 (SCA); 2008 (5) SA 339 (SCA) (30 May 2008). Saflii Website: http://www.saflii.org/za/cases/ZASCA/2008/78.html. [Last Consultation Date: December 13 2018].

${ }_{53}$ Meat Safety Act No. 40 of 2000 which sets out methods of slaughter and exceptions.

${ }^{54}$ Again, here I have only mentioned a few of the relevant laws and the list is not exhaustive.

${ }^{55}$ National Environmental Management Act, 107 of 1998 (NEMA). Ecolex Website:

https://www.ecolex.org/details/legislation/national-environmental-management-act-1998-no-107-of-1998-lex-faoc018752/. [Last Consultation Date: December 132018$].$

${ }^{56}$ National Environmental Management: Biodiversity Act, 10 of 2004 (NEMBA). National Department of Agriculture Website: https://www.nda.agric.za/docs/NPPOZA/NEMBA.pdf. [Last Consultation Date: December 13 2018]. There are however a number of SEMAS, another example is a SEMA that regulates "Protected Areas".

${ }^{57}$ These include CITES-specific regulations; regulations in respect of the trade of rhino horn; hunting activities and various others.

${ }^{58}$ Threatened or Protected Species Regulations, 2007. As the name suggests, the regulations apply to animals that are threatened or require protection. It sets out "restricted activities" in respect of these species, and the process to go about obtaining permits for these. Department of Environmental Affairs Website:

https://www.environment.gov.za/sites/default/files/legislations/nemba threatenedspecies_regulations_g29657rg8638gon152.pdf. [Last Consultation Date: December 13 2018].

59 Adopted in 2008. Notably, these are in the process of being amended by Government. Department of Environmental Affairs Website: https://www.environment.gov.za/sites/default/files/gazetted_notices/nemba elephantsinsa_g30833gon251.pdf. [Last Consultation Date: December 13 2018]. Other examples include the "Norms and Standards for the Management of Damage-causing Animals".

${ }^{60}$ In November 2018, the DEA proposed amendments to the Norms \& Standards but these have not yet been passed.

${ }^{61}$ It was the Constitution that formally integrated "Bantu lands", created during Apartheid into the existing four colonies and divided these into nine.

${ }^{62}$ Supra, Center for Environmental Rights \& Endangered Wildlife Trust, note 42.

${ }^{63}$ Although some of these standards have been incorporated into legislation.

42 Derecho Animal. Forum of Animal Law Studies, vol. 10/1 
the standards are not easily accessible as they must be purchased in order to be viewed and cannot be shared due to copyright restrictions.

If one looks at the regulation for pigs as an example, ${ }^{64}$ the SABS standards relating thereto were drawn up by the Livestock Welfare Co-ordinating Committee, ${ }^{65}$ the South African Pork Producers Organization, the Pig Veterinary Society and the NSPCA. Although the NSPCA is often part of the "technical committee" on the drafting of standards on animal related matters, they are inevitably only one voice among many with vested interests and are limited in their actions. This is but one example of standards, the committees responsible for the drafting of which are similarly composed. Animals are not even given a proper seat at the table, as they are already on the plate.

This self-regulation of critical animal issues and almost sovereignty of industry provides a false sense that there is sufficient regulation. However, these regulations generally operate on the assumption of the necessity of use, bare minimum protections, ensuring future operations and little concern for animals themselves. Although some standards are better than others and welfare provisions may be provided for, the non-binding nature and lack of sanction for non-compliance means they are of little value in providing genuine animal protection - and merely perpetuate the status quo.

\section{International and Regional}

For the sake of completeness and context, I set out below some of the international and regional obligations of South Africa in relation to animals. On an international level, South Africa has ratified some of the human-centric focused treaties relating to animals. ${ }^{66}$ It has however not signed on to the draft Universal Declaration of Animal Welfare (UDAW), which includes provisions recognizing, inter alia, the sentience of animals and the fact that good practices in animal welfare can have major benefits for humans and the environment. Another particularly relevant acknowledgement is that inclusion of animal welfare in policy discussions can strengthen efforts on human and animal health, food security, poverty and hunger reduction, disaster risk reduction and relief, environmental sustainability and social development. ${ }^{67}$

South Africa was one of the early parties to ratify the Convention on International Trade of Endangered Species of Fauna and Flora (CITES) in 1975. This treaty aims to ensure that international trade in specimens of wild animals and plants does not threaten their survival - which is in line with the domestic sustainable use policy. Based on an "exceptionalism" argument, namely that certain restrictions should not apply to South Africa, it has been granted some special carve outs. ${ }^{68}$ These include being granted a quota for an amount of lion skeletons for legal export each year, ${ }^{69}$ being granted a certain number of rhino hunting trophies per year, ${ }^{70}$ having its elephant population listed on Appendix $\mathrm{II},{ }^{71}$ and the exclusion of its crocodiles from the appendices. ${ }^{72}$

South Africa is also a party to the Convention on Biological Diversity (CBD) $)^{73}$ having ratified the

\footnotetext{
${ }^{64}$ Note that pigs are expressly included in the definition of "animal" in the Animal Protection Act, and thus do fall within its ambit. Their slaughter is also regulated by the Meat Safety Act, as aforementioned. However, despite these current legal protections, gestation and farrowing crates are still utilized and millions of pigs killed for food each year.

${ }^{65}$ Previously a committee of the Meatboard, that advises government on related livestock welfare policy and are funded by the Red Meat Industry. Other approved codes include those relating to cattle, sheep, pigs and goats on issues of slaughter, transport, goads and immobilizers. Livestock Welfare Coordinating Committee Website: http://lwcc.org.za/. [Last Consultation Date: December 9 2018].

${ }^{66}$ I am unable to delve further into this complex subject as various relationships and commitments affect our use of animals. For example, as a member of the Southern African Development Community, there are other policies that apply. There are also other important issues with CITES, South Africa's specific "gripes" with the treaty, its functioning and other parties or other specific factors.

${ }^{67}$ Universal Declaration of Animal Welfare. World Animal Protection Website: http://www.wspa-usa.org/wspaswork/udaw/. [Last Consultation Date: December 92018$]$

${ }^{68}$ CITES Appendices. CITES Website: https://www.cites.org/eng/app/appendices.php. [Last Consultation Date: December 92018$]$.

${ }^{69} \mathrm{Ibid}$, Appendix II see "Panthera Leo "For Panthera leo (African populations): a zero annual export quota is established for specimens of bones, bone pieces, bone products, claws, skeletons, skulls and teeth removed from the wild and traded for commercial purposes. Annual export quotas for trade in bones, bone pieces, bone products, claws, skeletons, skulls and teeth for commercial purposes, derived from captive breeding operations in South Africa, will be established and communicated annually to the CITES Secretariat."

${ }^{70} \mathrm{Ibid}$, Appendix II see Ceratotherium simum simum (Only the populations of South Africa and Swaziland; all other populations are included in Appendix I. For the exclusive purpose of allowing international trade in live animals to appropriate and acceptable destinations and hunting trophies. All other specimens shall be deemed to be specimens of species included in Appendix I and the trade in them shall be regulated accordingly).

${ }^{71}$ Ibid, Appendix II see Loxodonta africana (Only the populations of Botswana, Namibia, South Africa and Zimbabwe; all other populations are included in Appendix I). We were also allowed to sell ivory in CITES sanctioned activities.

${ }^{72}$ Crocodylus niloticus.

${ }^{73}$ Convention on Biological Diversity Website: https://www.cbd.int/. [Last Consultation Date: December 92018$]$
} 
convention in 1996, and is a member of the World Organization of Animal Health (OIE), ${ }^{74}$ which has standards relating to animal welfare..$^{75}$

On a regional level, being a member of the African Union, ${ }^{76}$ the recently developed Animal Welfare Strategy is very promising. ${ }^{77}$ It contains express acknowledgement of the sentience of animals, something that domestic law fails to do in legislation. ${ }^{78}$

\section{Case Law}

Turning our attention to the judicial system, unlike in other jurisdictions, animal law in the courts has been limited. ${ }^{79}$ This may be due to a plethora of reasons; however, I submit this may be due to two main factors. The first factor relates to costs, being both the cost of legal representation itself as well as costs of litigation. As per English law, the principle of "cost follows the result" applies, meaning that a successful party should be allowed to recoup their costs. ${ }^{80}$ Considering the general financial situation of most animal organizations and their access to generally costly legal advice, compared with that of those in the animal use industries (top players in industries generally employ top tier law firms), the threat of having to pay these costs in addition to their own serves as a great deterrent against litigation. ${ }^{81}$ This is further hindered by a specific provision in the Animal Protection Act which states that costs can be awarded against a "vexatious complainant". ${ }^{82}$ However, the Constitutional Court has affirmed a new approach to the issue of costs in constitutional litigation in the public interest, aimed at facilitating such litigation. ${ }^{83}$

The second factor is broadly capacity, being, aside from monetary resources, the lack of specific legal, technical and scientific knowledge required, organizations being otherwise overburdened with practical issues and lack of interest in these cases, particularly prosecutors in the criminal arena.

In terms of standing for animal law cases, South Africa may not necessarily face the same challenges as other jurisdictions do. ${ }^{84}$ This is due to the broad enforcement of rights provisions contained in the Constitution. These provide that anyone may approach a competent court, alleging that a right in the Bill of Rights has been infringed or threatened, acting in the public interest. ${ }^{85}$ Here it is also worth noting that as the NSPCA has a legislative mandate to protect animals, standing is generally not an issue for this organization. ${ }^{86}$

74 World Organisation for Animal Health Website: http://www.oie.int/. Standards for animals: http://www.oie.int/animalwelfare/oie-standards-and-international-trade. [Last Consultation Date: December 92018$]$

75 Other international memberships include the World Trade Organization (WTO) previously GATT. We are also a party to environmental and climate change treaties such as the Paris Agreement.

${ }^{76}$ African Union Website: https://au.int/memberstates. [Last Consultation Date: December 92018$]$

77 Released by the African Union in 2017 through the Africa Platform for Animal Welfare (APAW) with the secretariat at Africa Union InterAfrican Bureau for Animal Resources. World Animal Net Website:

http://worldanimal.net/images/stories/documents/Africa/AWSA.pdf. [Last Consultation Date: December 92018$]$

${ }^{78}$ Aside from statements by the courts, and in the aforementioned Elephant Norms and Standards. There have been notable efforts to get this expressly recorded in legislation (led by Beauty Without Cruelty - a South African animal rights group) and requests made to both the DEA and DAFF in this regard, although nothing has yet materialized.

${ }^{79}$ Despite these areas warranting further review, I have not dealt in detail with criminal prosecution of unlawful animal activities, including wildlife crimes. I have not delved into issues with our court system generally and other issues relating to access to justice. These are complex issues outside the scope of this paper.

${ }^{80}$ For a full analysis of costs in litigation, please see DUNSTAN M. The reform of the costs regime in South Africa: Part 2. Paper delivered at the Middle Temple and SA Conference by Justice Dunstan Mlambo, Judge President of the South and North Gauteng High Courts https://www.sabar.co.za/law-journals/2012/august/2012-august-vol025-no2-pp22-33.pdf. [Last Consultation Date: December 102018$]$.

${ }^{81}$ Although there have been some developments in this regard with respect to Constitutional Rights, these have not yet been applied in the animal law context. For further information, see Derebus Website: http://www.derebus.org.za/litigation-costs-inconstitutional-matters/. [Last Consultation Date: December 102018$]$

${ }^{82}$ Section 9 of the Animal Protection Act states: "Costs may be awarded against vexatious complainant - If at the trial of any person on a charge of an offence under this Act, the court is satisfied that any person or body has without reasonable cause and vexatiously lodged or caused to be lodged the compliant which led to such trial, it may award costs, including attorney and client costs, on the magistrate's court scale, against such person or body as if the proceedings were civil proceedings between the accused and such person or body."

${ }^{83}$ See Biowatch Trust v Registrar Genetic Resources and Others (CCT 80/08) [2009] ZACC 14; 2009 (6) SA 232 (CC); 2009 (10) BCLR 1014 (CC) (3 June 2009). Saflii Website: http://www.saflii.org/za/cases/ZACC/2009/14.html. [Last Consultation Date: December 12 2018].

${ }^{84}$ Such as, for example, in the United States, which has very specific standing requirements in the Constitution. This has thwarted may attempts at getting better protection for animals. An exception is the citizen suit provision in the Endangered Species Act (Section 11 or 1540 of 16 U.S.C. Sections 1531-1544).

${ }^{85}$ As aforementioned, animals are not mentioned themselves in the Constitution, nor are they legal persons, however guaranteed human rights can and are linked with animal protection.

${ }^{86}$ The issue of standing warrants further consideration. For a full analysis on standing of animals in South African law, although from 2001 is comprehensive, please see: YOUENS, K. Animal Rights A Moral And Legal Discussion On The Standing Of Animals 
I now turn to some examples of past animal law cases in the courts that have not yet been discussed above. The NSPCA in addition to prosecuting animal cruelty cases has launched significant litigation for animals. Most recently, the organization filed a suit to interdict the DEA and others from issuing further permits to captive lion breeders. ${ }^{87}$ This was related to the DEA's announcement increasing the CITES annual lion bone quota from 800 lion skeletons in 2017 to 1500 lion skeletons in 2018. The NSPCA challenged this decision based on failure by the DEA to comply with certain provisions of NEMBA and on further grounds relating to the captive lion breeding industry. ${ }^{88}$ The case has not been settled and notably since it was launched the DEA subsequently reduced the lion bone quota to 800 skeletons for $2018 .{ }^{89}$

Conversely, administrative law has also been utilized by those in animal use industries - such as breeders of wildlife. The first case was brought by a predator breeding association and hunters that involved a challenge to the validity of regulations that sought to severely restrict the practice of canned lion hunting (in terms of NEMBA). ${ }^{90}$ The challenge achieved substantial success, subject to certain technical issues.

The second case involved an application by (among others) the owner of the current largest rhino population in the world, in relation to the moratorium placed by the government on the domestic rhino horn trade (in terms of NEMBA). ${ }^{91}$ The applicants alleged that in making the decision to implement the moratorium, the government had failed to follow the necessary consultation process required in legislation. The court found in favour of the breeders, and thus in 2017 the domestic rhino horn trade once again became legal. ${ }^{92}$

In the criminal law arena, a notable case was that before the Supreme Court of Appeal (SCA) in 2014 (the second highest court in South Africa on most matters). The case was an appeal of a sentence given to Lemthongthai, hailed as one of Asia's most notorious wildlife traffickers, for his role in the illegal rhino trade. ${ }^{93}$ The court stated that "constitutional values dictate a more caring attitude towards fellow humans, animals and the environment in general". The court concluded further that this obligation was especially pertinent because of our history. This judgment was later referred to by the Constitutional Court who stated that this indicated that the rationale behind protecting animal welfare had shifted from merely safeguarding the moral status of humans to placing intrinsic value on animals as individuals. ${ }^{94}$

Notably, the SCA in its judgement mentioned that dealing with these crimes too leniently sends the wrong message. However, the court reduced the sentence of Lemthongthai. Furthermore, earlier this year, he was released from prison early, after only serving a small portion of his sentence, and he flew back to

In South African Law. Youens Attorneys Website: https://youensattorneys.co.za/wp-content/uploads/2016/08/animal-rights.pdf. [Last Consultation Date: December 9 2018]. Another example is an analysis on standing relating to environmental law in South Africa, see MQINGWANA, B. An analysis of locus standi in public interest litigation with specific reference to environmental law: a comparative study between the law of South Africa and the law of the United States of America. Pretoria University Repository Website: https://repository.up.ac.za/handle/2263/27926. [Last Consultation Date: December 112018 ].

${ }^{87}$ Captive lion breeding is a huge industry in South Africa with lions used in cub-petting, trophy hunting, canned lion operations and their skeletons exported internationally. Recently, the Parliamentary Portfolio Committee on Environmental Affairs (PCEA) adopted a 24-page report on Captive Lion Breeding for Hunting and Bone Trade in South Africa where they made resolutions to review the industry in South Africa. This was due to the tireless work of various organizations and a "Coalition against the breeding and keeping of lions and other big cats for commercial purposes". It was also due to undercover investigations undertaken by animal groups such as Ban Animal Trading and the EMS Foundation. See EMS Foundation Website: https://emsfoundation.org.za/wpcontent/uploads/Report-of-the-Portfolio-Committee-on-Environmental-Affairs.pdf [Last Consultation Date: December 142018$]$

${ }^{88}$ Full papers Docdroid Website: https://www.docdroid.net/0CAt7Nu/case86515-17-nspca-lionbones.pdf. [Last Consultation Date: December 132018$]$

${ }^{89}$ Notably, this was done in terms of a broad announcement by the DEA in December 2018, that its newly appointed Minister would be appointing a high level panel to review policies relating to matters of elephant, lion, leopard and rhinoceros handling, management, breeding, hunting and trade.

DEA Website: https://www.environment.gov.za/mediarelease/mokonyanetoappointhighlevelpanelreviewforpolicies [Last Consultation Date December 1320187.

${ }^{90}$ SA Predator Breeders Association and Others v Minister of Environmental Affairs and Tourism (72/10) [2010] ZASCA 151; [2011] 2 All SA 529 (SCA) (29 November 2010).

Saflii Website: http://www.saflii.org/za/cases/ZASCA/2010/151.html. [Last Consultation Date December 13 2018]. I have not discussed this further as Bilchitz provides a detailed analysis of this case in his paper. Supra, Bilchitz note 30.

${ }^{91}$ John Hume was one of the applicants in the case of Kruger and Another v Minister of Water and Environmental Affairs and Others (57221/12) [2015] ZAGPPHC 1018; [2016] 1 All SA 565 (GP) (28 November 2015). Saflii Website: http://www1.saflii.org/cgi-bin/disp.pl?file=za/cases/ZAGPPHC/2015/1018.html\&query=hume. [Last Consultation Date: December $132018]$

${ }^{92}$ This issue is an interesting but highly controversial one and receives much national and international attention. One of the debates is whether the international legalization of the trade will help protect or further harm rhinos, with both sides vehemently defending their view. This issue will undoubtedly present itself in South Africa's submission at the next CITES Conference of the Parties (COP 18) next year.

93 Lemthongthai v S (849/2013) [2014] ZASCA 131; 2015 (1) SACR 353 (SCA) (25 September 2014). Saflii Website: http://www.saflii.org/za/cases/ZASCA/2014/131.html. [Last Consultation Date: December 13 2018]

${ }^{94}$ Supra, NSPCA Case note 32. 


\section{Thailand.}

The above reflect some of the ways that animals' interests have been addressed in and by the courts. Looking forward, there is vast opportunity to utilize the judicial system to get better protection for animals, particularly in the field of administrative law and given recent statements by the courts. This avenue needs to be explored carefully and strategically in order to bring about law reform, particularly where the legislative route is unsuitable. ${ }^{95}$

\section{Linking animal interests with human interests in South Africa}

\section{Introduction}

The prerequisite to account for the interests of all in the legal system has never been more pertinent or relevant than it is today, and particularly in a country such as South Africa. Accordingly, it is essential that the field of animal law is developed - either by working within and interpreting the existing framework or by expanding and developing it, where relevant.

In this section, I illustrate some of the ways in which abuse of animals affects humans. By providing examples of intersectional areas, I hope to demonstrate why failing to consider animal interests on their own, as well as together with human interests, negatively impacts both parties.

By this failure, the current policies and systems essentially enforce notions rooted in colonialism and apartheid, thereby promoting values contrary to the Constitution, and are accordingly unsuitable in a democratic society. Even where interests have the potential to, and will inevitably, conflict, this is not a justifiable reason to exclude them $a b$ initio. If and when such rights and interests conflict, the legal framework must, and already does, provide mechanisms to deal with this.

It may be considered a fundamental error by those in animal protection to argue that animals should be protected because of the potential impact on humans, and not for their own reasons. Although I agree with the rationale behind this argument, I believe that it doesn't have to be an "either or" situation. The ideas are not fundamentally opposed, but rather work in tandem. Greater protection for animals can and does often mean greater protection for humans. Additionally, what I propose is a further consideration - that when human interests are being considered in the equation, these should encompass the interests that humans have in the protection of animals, and not only their interests in 'using' animals.

For the purposes of this section, I assume under each heading that animal cruelty or suffering is present in most if not all animal use activities relating thereto, and so I have not repeated this throughout. Animals, accordingly, have their interests infringed throughout - including their interests to bodily integrity, dignity, life, freedom, interests to be free from harm, suffering and others. ${ }^{96}$. Further, many of these issues overlap and intersect with each other, thus reinforcing the necessity of a holistic approach.

\section{Country view: Tourism and international opinion}

As aforementioned, South Africa is world-renowned for its animals, with people coming from all over the globe to participate in animal-related activities, thus boosting tourism and the economy. Popular pursuits include safaris, shark cage diving and several forms of hunting. In 2017 alone, over 10 million foreign tourists visited South Africa. The old Western adage of "if it pays it stays" is extremely apparent in its wildlife policies. ${ }^{97}$ Due to its population of popular wild and exotic creatures, policies and laws relating to its wildlife inevitably receive a large amount of worldwide attention. However, according to recent reports, revelations about the truth and scale of the canned lion hunting and captive lion breeding industry and its direct links with the lion bone industry have seriously tarnished South Africa's image, essential for

\footnotetext{
${ }^{95}$ For interest, a case dealing with cultural rights and animal protection is that of Smit NO and Others v King Goodwill Zwelithini Kabhekuzulu and Others (10237/2009) [2009] ZAKZPHC 75 (4 December 2009). Saflii Website: http://www.saflii.org/za/cases/ZAKZPHC/2009/75.html. [Last Consultation Date: December 12 2018]. Bilchitz has criticized this judgement based on the fact that the judge made his decision without directly addressing the legal questions that arose. The failure to disclose a sufficient factual foundation for the application was determinative in his view and allowed him to avoid having to weigh up the infringement of the laws protecting an animal against cruelty against the right of the community to practice their religion and culture.

${ }^{96}$ Except however, the last category relating to family - where a positive interest is included.

${ }^{97}$ For example, in the DAFF Veterinary policy, the game ranching industry is described as a "largely unsung success story" and considering game ranching has such massive potential and is one of South Africa's unique forms of agriculture, which provides SA with a competitive edge, it should be prioritized to be promoted and export markets opened. Similar sentiments are echoed in DEA policies in relation to animals in the wild.
}

46 Derecho Animal. Forum of Animal Law Studies, vol. 10/1 
attracting overseas tourists. ${ }^{98}$ This is but one example of how animal policies can impact the country and its reputation on a global scale and how as a citizen of the country, one has an interest in promoting the protection of animals.

\section{Violence and crime}

The Constitution enshrines the right to be free from all forms of violence from either public or private sources. ${ }^{99}$ The Animal Protection Act also contains provisions making certain violent actions towards animals unlawful. Yet, as a country, South Africa is one of the most violent in the world. According to the latest statistics, crime in South Africa is on the increase, fear is on the rise and trust in the criminal justice system has dropped. ${ }^{100}$

There is a large body of evidence globally illustrating "the link" between acts of violence towards animals and acts of violence towards humans and other related matters. ${ }^{101}$ Evidence has illustrated animal abuse, cruelty and neglect do not occur in a vacuum and cannot be considered isolated incidents wholly separated from other forms of family violence. This could not be more relevant given the different ways violence manifests in society. Recent statistics indicate that annually over 50,000 rapes (actually reported to the police - indicating only $73 \%$ of victims); over 350,000 cases of assault, which includes domestic violence; and nearly 17,000 murders occurred. ${ }^{102}$

Accordingly, in targeting violence against humans, specifically women and children, we must out of necessity consider all its victims. ${ }^{103}$ Further, by recognizing that violence to animals may provide early warning signs for violence to humans, we may prevent further harm. Finally, we cannot hope to reduce or eliminate violence among people while we sanction the largest scale of violence ever recorded on a daily basis, whether complicitly, such as in the food system, or explicitly, such as trophy hunting. All acts of violence in society, regardless of the victim, must be considered abhorrent and eliminated and all victims of such violence properly protected.

\section{Racial Considerations}

The Constitution guarantees the right to equality as well as non-discrimination on a number of grounds, including race. During apartheid, in addition to the other layers of segregation, food was also often set apart, with non-whites receiving lower grade and qualities of meats compared with the white populations, who received the higher qualities. Today, although not blatant, food segregation similarly exists, with poorer people, generally black and other previously disadvantaged groups, purchasing lower quality meats, such as polony. ${ }^{104}$

This becomes extremely relevant when one considers the fact that in 2017, South Africa had the largest outbreak of listeriosis ${ }^{105}$ ever recorded in history, ${ }^{106}$ with over 1000 people being infected and 216

\footnotetext{
${ }^{98}$ CACH UK \& SPOTS Captive Lion Breeding, Canned Lion Hunting \& the Lion Bone Trade: Damaging Brand South Africa? A review of the worldwide reaction to South Africa's captive lion breeding and canned hunting industry and involvement in the lion bone trade Netherlands, August 2018 https://conservationaction.co.za/wp-content/uploads/2018/08/CACH-Brand-SA-ReviewAugust-2018.pdf. [Last Consultation Date: December 9 2018].

${ }^{99}$ Section 12.

${ }^{100}$ Household crimes increased by $5 \%$ to a total of 1,5 million incidences of crime while individual crime also increased by $5 \%$ to a total of 1,6 incidences, affecting 1,4 million individuals aged 16 and above: Full report can be accessed at Statistics SA Website: http://www.statssa.gov.za/publications/P0341/P03412018.pdf. [Last Consultation Date: December 92018$].$

${ }^{101}$ While there is substantial literature and studies from around the world, South Africa seems to be lacking in terms of statistics and specific research. The NSPCA regularly refers to the link in its outputs and it is clearly prevalent in South African society NSPCA Website: https://nspca.co.za/wp-content/uploads/2016/05/Abuse.pdf. [Last Consultation Date: December 9 2018]. From a study on South African prisoners about their childhood animal abuse, of the 58 men who had committed crimes of aggression, 63.3 per cent admitted to cruelty to animals; of the 59 nonaggressive inmates, the percentage was 10.5 per cent. See ASCIONE, F. Animal Abuse and Youth Violence. U.S. Department of Justice Website: https://www.ncjrs.gov/pdffiles1/ojjdp/188677.pdf. [Last Consultation Date: December 1120181.

${ }^{102}$ Notably, the source of these statistics only mentions animals in relation to their incidences of theft and not in relation to crimes against them, thus indicating part of the problem.

${ }_{103}$ There are various states in the USA for example that include companion animals in Protection Orders, and recording same in legislation in South Africa could be a useful tool at ensuring protection for both humans and animals.

104 Polony is a meat made from parts that are generally described as "off-cuts". After an animal is slaughtered, the producers typically cut the marketable cuts, leaving trimmings and pieces of meat on the bone. These are all the pieces of meat that are not a specific, marketable cut.

${ }^{105}$ Listeriosis is serious infection caused by the germ Listeria monocytogenes found in contaminated food.

106 More information on this case can be accessed here: Listeria Class Action Website: https://listeriaclassaction.co.za/.[Last Consultation Date: December 122018$].$
} 
deaths. Of these, $85 \%$ of the victims were black, $7 \%$ were coloured, ${ }^{107} 7 \%$ were white, and less than $1 \%$ were Asian. Notably, within these categories, most affected were the more vulnerable members of society children, pregnant mothers, the elderly, and those with compromised immune systems. ${ }^{108}$ Although listeria occurs widely in nature, ready-to-eat processed meat products are particularly susceptible to contamination. Although unintended, consequences of the current food system negatively impact upon both animal and human lives.

A further example of regulation that is both oppressive to animals and people is in the arena of wildlife. The passing of certain legislation prior to the end of apartheid that transferred property rights from the state to private landowners has had major implications and continues to divide races, separate communities from wildlife and impact society as a whole. This can be seen in the current ownership of wildlife, such as in the game farming industry which is dominated by white Afrikaans-speaking males. ${ }^{109}$

The hunting industry more generally is still dominated largely by white males that have preserved practices that are both discriminatory and racialized. ${ }^{110}$ Examples of this include the treatment of (mostly black) farm workers including in relation to their wages; safety when dealing with dangerous animals, as well as their vulnerability to have residential arrangements terminated without proper notice.

Racial tension also exists when one considers the attention given to wildlife crimes such as rhino poaching, compared with the harsh living conditions of so many people within previously disadvantaged groups, affirming a belief that "wildlife is prioritized over black rural lives". ${ }^{111}$ However, with appropriate wildlife policies that integrate respect for both people and animals, both may benefit.

\section{The toxic relationship with food}

Since the end of apartheid, South Africa's food consumption has shifted towards a more Westernorientated diet, much to our detriment.

As a result of this shift, agricultural systems and practices have changed. Current agricultural practices both domestically and globally have become increasingly unsustainable. Heavy reliance on animal-based protein has mechanized food production in such a way and to an extent that depletes natural resources and contributes to environmental degradation and habitat loss. These production methods treat animals as mere instruments in acts of unspeakable cruelty behind closed doors.

The Constitution guarantees the right to sufficient food and water and provides that the state must take reasonable legislative and other measures to achieve the progressive realization of each of these rights. ${ }^{112}$ If one considers the fact that the agriculture industry in South Africa utilizes the most water of any other industry, and then considers the current water situation. ${ }^{113}$ This issue warrants further exploration.

Furthermore, the current scale of agricultural and fishing practices and their contribution to the greenhouse effect and global warming are widely problematic. Given the ever-growing human population and climate change, food security is a major concern. People's addiction to meat and its effects on us has created a dangerous dependency.

This toxic relationship affects multiple guaranteed human rights as well as animal interests. The right to environment is clearly affected when one considers the detrimental impact of current practices on land, air, soil, water and oceans. Furthermore, eating animals affects human health in multiple other ways such as the transfer of zoonotic diseases, ${ }^{114}$ the rise of antibiotic resistance development, ${ }^{115}$ and increased

\footnotetext{
${ }^{107}$ A previously defined race of persons during apartheid, but commonly utilized term in South Africa today. Britannica Website: https://www.britannica.com/topic/Coloured. [Last Consultation Date: December 122018 ].

108 The class action refers to the infringement of relevant constitutional rights as well as legislation and duties of the defendant. In the future, it may be possible to include animal interests in the discussion, if infections are as a result of farming activities. In this instance, the bacterium was traced back to the abattoir and no mention of the live animals containing the bacterium is made.

109 SPIERENBURGAB M \& BROOKS S. Private game farming and its social consequences in post-apartheid South Africa: contestations over wildlife, property and agrarian futures, Journal of Contemporary African Studies 32 (2014) http://www.tandfonline.com/loi/cjca20. [Last Consultation Date: December 11 2018].

${ }^{110}$ See for example: FEMKE BRANDT \& MARJA SPIERENBURG Game Fences in the Karoo: Reconfiguring Spatial and Social Relations Journal Of Contemporary African Society (2014) 1-18. (https://doi.org/10.1080/02589001.2014.925300) [Last Consultation Date: December 11 2018] and MKHIZE, N. Game Farm Conversions and the Land Question: Unpacking Present Contradictions and Historical Continuities in Farm Dwellers' Tenure Insecurity in Cradock Journal Of Contemporary African Society 32 (2014) 207-219 (https://doi.org/10.1080/09637494.2014.937164) [Last Consultation Date: December 112018 ].

111 GRIFFITHS, M. Heritage lost: The cultural impact of wildlife crime in South Africa, SA Crime Quarterly (2017) 45-50. (http://dx.doi.org/10.17159/2413-3108/2017/v0n60a1728) [Last Consultation Date: December 112018$].$

112 Section 27.

${ }^{113}$ Cape Chameleon Website: The Water Footprint of What We Eat https://capechameleon.co.za/the-water-footprint-of-what-weeat/. [Last Consultation Date: December 122018$].$

${ }^{114}$ Centers for Disease Control and Prevention Website:

https://www.cdc.gov/globalhealth/countries/southafrica/what/one health.htm. [Last Consultation Date: December 13 2018].

48 Derecho Animal. Forum of Animal Law Studies, vol. 10/1
} 
obesity rates. ${ }^{116}$

Adding to all of this is the often-deceitful methods that industries use in promoting and labelling these foods. Terms such as "humane", "cage free" and even "sow friendly" found on animal products reinforce the disconnect between humans and the non-human animals they consume. They provide consumers with a false sense of comfort that their habits are somehow more considerate, yet the realities are far from that.

The disconnect is not limited only to animals, but expands to those that are required to slaughter them, day in and day out, for minimal wage. Slaughterhouse workers also suffer terribly, such as from posttraumatic stress disorder, ${ }^{117}$ and have their interests violated by the same industry violating animal interests.

\section{Land}

Land reform policies have for over a century caused controversy and much disruption in the country. This subject is highly complex and outside the scope of this article. Worth noting, however, is the fairly recently proposed constitutional amendment which would provide for land expropriation without compensation. This has left the country in a flurry with many predicting dire consequences.

Although it is unclear exactly how these proposals will play out, the consequences of these policies will inevitably have an impact on both humans and animals - particularly in relating to agriculture, animal practices and land and water use.

\section{Family}

Millions of animals are kept in people's homes and thus companion animals form a major part of many people's lives. This particular category of animals has increasingly come to be accepted as part of the "family" in many groups in South Africa, regardless of race, class economic capabilities or other factors. ${ }^{118}$ Arguably, legal protections relating to family could be expanded to include its nonhuman counterparts. Moreover, as referred to above, by sensitizing case workers and police to "the link", abuses in family settings may be reduced. Treatment and policies relating to companion animals inevitably impact the interests of animals and humans.

\section{Corruption}

As a final point, it is important to mention the role that corruption has played and continues to play in South African society and the damaging impact thereof. Both the apartheid government ${ }^{119}$ and the current government under the new democracy ${ }^{120}$ have been implicated in animal crimes, mostly relating to wildlife. Furthermore, there has been a betrayal by groups tasked as guardians of animal and public interests, such as park rangers and the South African Police Services who have been implicated in crimes and syndicates. In addition to this, failure to hold relevant persons accountable for their role in illegal activities has reinforced

\footnotetext{
115 VAN DEN HONERT, M. S.; GOUWS, P. A. and HOFFMAN, L. C. Importance and implications of antibiotic resistance development in livestock and wildlife farming in South Africa: A Review. South African Journal of Animal Science 48 (2018) 401 412 (http://dx.doi.org/10.4314/sajas.v48i3.1) [Last Consultation Date: December 13 2018].

${ }^{116}$ RONQUEST-ROSS L-C, VINK N, SIGGE GO. Food consumption changes in South Africa since 1994. South African Journal of Science (2015) 111 (http://dx.doi.org/10.17159/ sajs.2015/20140354). [Last Consultation Date: December 132018 ].

117 VICTOR K \& BARNARD A. Slaughtering for a living: A hermeneutic phenomenological perspective on the well-being of slaughterhouse employees International Journal of Qualitative Studies on Health and Well-being (2016) 11:30266. (doi:10.3402/qhw.v11.30266) and K VICTOR AND A BARNARD Post-traumatic stress of employees working as slaughterers' UNISA University, http://uir.unisa.ac.za/bitstream/handle/10500/18454/PTSD\%20Slaughtering\%20Poster\%20A\%20Barnard\%202003.pdf?sequence=1 [Last Consultation Date: December 9 2018].

118 A successful organization in South Africa is CLAW (Community Lead Animal Welfare). CLAW's holistic non-exclusive approach and CLAW's extended network is improving the lives of thousands. CLAW distributes food parcels, facilitates a homebased care programme to teach people how to care for the sick and dying, runs food gardens, supports child-headed households and helps communities access health and hospice care. CLAW. Website: http://www.claw-sa.org/about.html. [Last Consultation Date: December 112018$]$.

119 Studies have indicated the apartheid state's involvement in the ivory and rhino horn trade structures of the 1970s and 1980s by showing how these illicit trades financed the South African secret services and individuals linked to them. For a full and in-depth discussion of the rhino horn trade, I highly recommend the magna carta HÜBSCHLE, A. A Game of Horns: Transnational Flows of Rhino Horn (2016) ISBN: I978-3-946416-12-8, (DOI: 10.17617/2.2218357).

${ }^{120}$ Conservation Action Trust. Website: Failure To Prosecute And Mixed Messages: How South Africa can single-handedly lose the second rhino war - Report: https://conservationaction.co.za/resources/reports/failure-prosecute-mixed-messages-south-africa-cansingle-handedly-lose-second-rhino-war/. [Last Consultation Date: December 13 2018]
} 
the idea of impunity.

Wildlife crimes are increasingly being recognized for their largely devastating and far-reaching effects. These have been linked to a host of other problems such as drug, human and weapon trafficking, their funding of terrorist activities, and the effect on national safety.

\section{Animal Law Reform: Looking ahead}

\section{Introduction}

As the need for change has been established, we need to contemplate how to achieve this. For it to occur, there will need to be changes made at multiple levels, across sectors and by various stakeholders. ${ }^{121}$ However, for my purposes I will focus on achieving change through the South African legal system. I will include a proposal for an overall approach and make suggestions in a few key areas. It is important to note that there is a myriad of potential avenues that can, and should be explored further.

South Africa is in a unique position due to its underdeveloped field of animal law. This provides the country with an opportunity to learn from other jurisdictions - such as the how and why of their failures and successes. Despite different laws and circumstances, their decades of experience have undoubtedly created some sort of guide that we can learn from and adapt to a South African context and legal system. ${ }^{122}$ Although a comparative analysis on how jurisdictions have achieved change for animals through their legal system would undoubtedly prove useful, it is outside the scope of this particular article, but something I intend to explore in future.

We likewise can learn from the country's own social justice movements, taking relevant factors into account and utilizing these to our advantage. Therefore, we may "pre-empt" some of the obstacles and challenges with obtaining animal protection and explore how to potentially counteract these.

\section{Rectifying the current obstacles and difficulties}

Although a transformation in approach is still required, it may be more realistic to commence with reform by "repairing" the existing framework. Without being repetitive, these include (but are not limited to): closing existing loopholes such as the exclusion of certain animals from protection; defining confusing provisions; including animal welfare as a mandate for all departments that interact with animals; legislating for suitable criminal and non-criminal penalties; allocating funds and resources to animal issues; and unifying procedures across jurisdictions to some extent.

The idea is not too implausible given the growing pressure on government and the private sector by the public; and the increase in the animal protection movement - including marches and protest activity. ${ }^{123}$ Additionally, politicians are becoming increasingly open to being lobbied on animal matters, assisted by opportunities for members of Parliament to introduce legislation by means of private member's bills. ${ }^{124}$ Additionally, DAFF has made numerous public statements about amending the APA, although this is taking many years to materialize and the proposed amendments are unclear.

\section{Approach to policy and decision making in administrative action}

In order to properly account for animals, I submit that when administrative actions or decisions (broadly defined) are being made or actioned, the potential material or adverse effects on animals must be considered. Animals must thus be considered as stakeholders. This may be done by a two-staged approach. I refer to as the Integrational Approach, which builds on the Integrative Approach.

121 The role of, for example, veterinarians, the South African police services, scientists, educators, academics, rangers, communities as well as corporates is essential. Sensitizing and educating these stakeholders on animal interests and related issues would be extremely beneficial in creating long-term change.

122 Animal law has been an acknowledged and recognized field in America for many years. See TISCHLER.J, The History of Animal Law, Part I (1972-1987) Stanford Journal of Animal Law \& Policy 11 (2008)https:/law.stanford.edu/wpcontent/uploads/2018/05/tischler-1.pdf [Last Consultation Date: December 14 2018] and TISCHLER.J A Brief History of Animal Law, Part II (1985 - 2011) Stanford Journal of Animal Law \& Policy 5. (2012) https://www.animallaw.info/sites/default/files/tischler2012.pdf. [Last Consultation Date: December 14 2018]

${ }^{123}$ A notable organization that undertakes protest activity is Ban Animal Trading, one of the largest animal rights groups in the country. They additionally conduct undercover investigations and utilize various legal and non-legal methods.

${ }^{124}$ See private members bill amending the Animal Protection Act introduced in December 2017 to amend the act to ban cosmetic testing on animals currently being considered by Parliament. Parliament Website: https://www.parliament.gov.za/storage/app/media/Docs/bill/74740ec4-a141-4451-90ba-ebc6a1f0f415.pdf [Last Consultation Date: December 12 2018]. 
The first leg of the Integrational Approach includes the recognition, consideration and application of animal interests in their own right. This is the integrative approach described by Bilchitz and subsequently adopted by the Constitutional Court.

The second leg considers the interests of animals as integrated with those of humans, namely the interests that humans have in the protection of animals. ${ }^{125}$ Within this, there is consideration of the overall impact that decisions have across sectors, in light of constitutional values and impact on both current and future generations. ${ }^{126}$ This builds on the examples from the previous section, that issues do not occur in a vacuum and need to be considered holistically. They also need to be considered not only in light of prevailing circumstances, but future impact.

In order to ensure this principle is given "teeth", there needs to be a sensitization as to what animal interests are, and the various ways in which these intersect with human interests. Thus, consulting with relevant stakeholders and experts will be essential, and if functions are required to be performed, these must be done by specialist, organized bodies, where relevant.

Suggestions by others as to how to account for animal interests include Meyersfeld ${ }^{127}$ who refers to three co-existing principles that must be included in a regulatory system with an animal-centric component. There are (i) the absence of pain, (ii) glass slaughterhouses, and (iii) the imperative of survival, which could also be included within this approach to some extent.

Taking into account the above overarching approaches, how then should animals' interests be accounted for in the legal system?

\section{Legislative Efforts}

Bilchitz argues that the most preferable way to account for animals' interests in the legal system would involve a constitutional amendment whereby the rights of animals would be explicitly protected directly in the Constitution itself. ${ }^{128}$ Given the process and requirements alone for this, aside from the realities of such a provision even being considered, this is unlikely to happen. ${ }^{129}$

His second suggestion, that the Constitution can convincingly be interpreted to recognize the dignity and interests of animals, has since been formally confirmed by the Constitutional Court. As the court has recognized the intrinsic worth of animals, akin to dignity, the question then becomes what the implications of this are going forward. As these are still unclear, in the interim we may seek to explore how other laws may be utilized to account for the interests of animals.

One example could be by the extension of current administrative law protections offered to persons, to animals. The right to just administrative action is contained in the Constitution, and the legislation through which this right is primarily implemented (Promotion of Administration of Justice Act or PAJA) requires that administrative action which materially and adversely affects the rights or legitimate expectations of any person must be procedurally fair. ${ }^{130}$ Additionally, when administrative action materially and adversely affects the rights of the public, further requirements are set out. I submit that the same protections offered to persons in PAJA can and should be granted to animals when administrative action materially or adversely affects them. Existing administrative law provisions contained in other specific legislation can be expanded on and work in tandem.

Following on from this, loopholes available for self-regulated industries must be closed. This can be done through formal passing of legislation through the relevant consultation and other processes. Or, if selfregulation persists, it must be subject to similar principles of consultation and procedural fairness. Presumptions in favor of animal use should be amended to required justification thereof.

Looking more broadly, along with laws protecting animals, there should be laws supporting protection efforts and activists, especially those involving transparency of animal practices. Similarly, laws harming animal protection efforts must be challenged against constitutional principles. Using the United States as an example, the animal-use industry has lobbied for "ag-gag" laws ${ }^{131}$ and laws that brand activists

\footnotetext{
${ }^{125}$ I do not specify the need to take into account human interests as this has been assumed. As a parallel consequence of this, we will see the interplay of animal law as a separate distinct field of law and as integrated with other areas of law.

${ }^{126}$ The concept of future generations must include both humans and animals in its ambit.

${ }^{127}$ MEYERSFELD, B. Non-Human Animals and the Law: The Fable of Power South African Public Law Journal (2012-2013).

${ }^{128}$ Supra, Bilchitz note 12.

${ }^{129}$ Although, there are now expressly recognized in various constitutions in the world that account for animals, such as Germany, Egypt India and others.

130 This right is contained in section 33. It is mostly implemented through the Promotion of Administration to Justice Act. Government Website: http://www.justice.gov.za/legislation/acts/2000-003.pdf [Last Consultation Date: December 10 2018].

131 For a further discussion on Ag-gag please see the Animal Legal Defense Fund's explanation. ALDF Website: https://aldf.org/issue/ag-gag/. [Last Consultation Date: December 9 2018].
} 
as "terrorists" 132 in attempts to dissuade collection and dispersion of information regarding animal practices. By criminalizing certain behaviors akin to whistleblowing and efforts to bring cruelty into the public eye, activists are being prohibited from obtaining necessary evidence relevant to animal and human protection. These laws are not only present in America but also in parts of Europe and Australia. By pre-empting such or similar actions by industry, legal protections for the movement and activists can be secured. ${ }^{133}$

\section{Judicial System}

As aforementioned, South Africa has limited litigation on animal law issues, but we do have a vast assortment of cases from the rest of the world that we can consider, bearing in mind our unique circumstances and legal framework. There is enormous opportunity for strategic cases to be brought in South African courts relating to animals, whether this is based on the laws protecting animals themselves, or through utilizing other areas such as environmental law, family law, human rights, consumer protection, food safety and labelling criminal law and others. ${ }^{134}$ This avenue is even more plausible given two factors. The first being that South African animal protection laws are not as restrictive in the animals that are offered protection - as compared with other jurisdictions. The second is due to some of the positive statements of the courts as aforementioned, indicating a shift towards growing recognition and concern for animals and their importance. This is not merely as commodities or for their value to humans, but for their value as individuals and their intrinsic worth.

A tool that will become vitally important in this arena and may present opportunities to bring animal interests to the attention of courts in decision-making is the amicus brief. In summary, an "amicus curiae" is a friend of the court. Provided the necessary elements can be proved, it serves as an opportunity for litigation without being a party. The role of the amicus brief in human rights litigation has been well established in South African law. ${ }^{135}$ This avenue is particularly relevant when the court is assessing complex areas of law, such as the (yet formally recognized) area of animal law. This tool has been used to ensure that vulnerable groups are given a voice in the judicial system, thereby potentially proving an invaluable tool for those in animal protection.

By coupling this with ensuring access to the court system for animals and those advocating on their behalf, they may be given a platform for ensuring justice. ${ }^{136}$ In conjunction with these efforts, judicial officers, prosecutors and others must be sensitized to the above Integrational Approach.

\section{Executive}

In actions and decision-making affecting animals, there needs to be meaningful consultation with stakeholders representing all interests. ${ }^{137}$ Those that have vested interests should not make up the majority of decision-makers. Thus, a "check the box" exercise simply will not suffice. The need to utilize the latest scientific information is critical, as is transparency.

Again, corruption needs to be eliminated and a feedback loop needs to be created ${ }^{138}$ with independent monitoring to ensure laws are succeeding in what they hope to achieve.

\section{Legal Practice}

In legal practice, lawyers should be encouraged to offer pro bono services to animal organizations and causes in addition to human organizations and causes. ${ }^{139}$ Lawyers should also form organized committees to

\footnotetext{
132 For a further discussion on the Animal Enterprises Terrorism Act, see the Civil Liberties Defense Center Website: https://cldc.org/animal-enterprise-terrorism-act-aeta/ [Last Consultation Date: December 11 2018]

${ }^{133}$ Notably there are a number of ways the laws have been used to thwart protective efforts such as "Mclibel law". The use of defamation and related tools are commonplace. Efforts to make protests more difficult are also employed, such as the use of defamation and other criminal laws.

${ }^{134}$ The route of using other areas of law to achieve animal protection is well documented in other jurisdictions, such as the USA, that has used for example, environmental laws to tackle the factory farming industry.

${ }^{135}$ MUBANGIZI, JC \& MBAZIRA C, Constructing the Amicus Curiae procedure in human rights litigation: What can Uganda learn from South Africa?, Law Democracy and Development 16 (2012) (http://dx.doi.org/10.4314/ldd.v16i1.11) [Last Consultation Date: December 9 2018].

${ }^{136}$ NYENTI, M, Access to justice in the South African social security: Towards a conceptual approach" Dejure 44 (2013). Saflii Website: http://www.saflii.org/za/journals/DEJURE/2013/44.html [Last Consultation Date: December 14 2018].

${ }^{137}$ And as aforementioned, should include animals themselves as stakeholders.

138 See for example AfricanLII Website: https://africanlii.org/blogs/andrewrens/feedback-loop-law-version-10 [Last Consultation Date: December 10 2018].

${ }^{139}$ Currently, it is not clear that hours dedicated towards animal causes would be considered as part of the required hours. Reference

52 Derecho Animal. Forum of Animal Law Studies, vol. 10/1
} 
work on these issues, such as the Animal Law Committee of the American Bar Association.

\section{Education}

Aside from humane education, which is enormously important and powerful, ${ }^{140}$ education on animal interests is essential. It should, where possible, be legislatively mandated for in professions such as veterinary sciences, conservation, environmental, and similar areas. For lawyers specifically, animal law should form part of the curriculum. I believe including animal law as a subject in legal education is essential. It provides an interesting case study for lawyers because it asks important questions of the law and requires lawyers to think critically and creatively, as may not be so pertinent in other areas. Such questions include: who does the law protect; what is the basis for this protection; what is wrong with the current framework; and how can I use it to my client (in this case, the animal)'s advantage? This education can be expanded to practicing lawyers in the form of continuing legal education.

Having animal law courses, or courses that incorporate animal law and animals into the conversation, will help legitimize the field and sensitize lawyers to these issues before they enter legal practice (in a similar way that they should be sensitized to human issues and legal issues therewith).

\section{Other efforts}

The role of organizations and non-legal efforts in the animal protection movement cannot be stressed enough. Due to their efforts, there has been a marked increase in interest in animal protection in recent years. This can be seen in the rise of animal-based protests and marches and the growth of veganism and vegetarianism, together with the demand for more "humane" products and many examples of public pressure on retailers in respect of their practices, suppliers and products.

It is absolutely essential that the animal protection movement and efforts in South Africa are inclusive in all respects and are not seen to be divisive (particularly on matters of race, gender and economic capabilities). Social justice movements are more successful when all interests are considered and efforts to dismantle oppressive systems are unified. This means being sensitive to both human and animal interests. It also means including communities, the private sector and others that play an important role in society.

There has also been an growth in the presence of international animal organizations in South Africa, increased efforts to educate the public on certain issues through the use of documentaries and other avenues, and the public becoming more involved and outspoken on certain animal topics, with one example being the huge push to ban fireworks at a national level.

Politicians are also becoming more vocal on these issues, either due to public pressure or their own views. One far-reaching statement was made by Prince Mangosuthu Buthulezi, who is a Zulu tribal leader who founded the Inkatha Freedom Party (IFP). In response to a letter requesting the formal inclusion of sentience in South African law in 2018, Prince Buthulezi stated: "We are not merely co-habitants on this planet with fauna and flora, but stewards and custodians, with a moral responsibility of protecting their wellbeing. But it is not our moral responsibility towards animals that bestows value on them. Animals have intrinsic worth. All animals, whether wild or domestic, are undoubtedly sentient beings."

He then refers to a quote from his friend, Lawrence Anthony: "Until we allow all living creatures their place in the sun, we can never be whole ourselves." ${ }^{141}$

These positive and incremental steps, however small, promote protection and can assist legal efforts for animals.

\section{Concluding Remarks}

To some, the obligation to consider the interests of another "group" within society may seem

is made to the Human Rights Commission, but otherwise, little guidance is given. See Derebus Website: http://www.derebus.org.za/clarity-pro-bono-legal-practice-act/ [Last Consultation Date: December 11 2018] and Legal Practice Act: https://www.lssa.org.za/upload/documents/Legal\%20Practice\%20Act\%20GG\%2038022\%20of\%2022\%20September\%202014.pdf [Last Consultation Date: December 112018 ].

${ }^{140}$ The Humane Education Trust in South Africa specifically works on humane education and has done so for years. Additionally, Kai Horsthemke has written substantially on the subject of education, particularly in Africa and South Africa and some approaches and considerations. I suggest his work be consulted particularly his latest book: "Animal Rights Education" The Palgrave Macmillan Animal Ethics Series: ISBN 978-3-319-98592-3 ISBN 978-3-319-98593-0 (eBook): (https://doi.org/10.1007/978-3-319-98593-0.) 141 Beauty Without Cruelty: Upon Receipt of a Petition From Beauty Without Cruelty and 84 Animal Rights NGOs Message of Support From Prince Mangosuthu Buthelezi MP President Of The Inkatha Freedom Party http://www.ifp.org.za/newsroom/beauty-without-cruelty/ [Last Consultation Date: 15 December 2018]. 
unnecessary, impossible, intolerable, unrealistic, or a waste of already constrained resources. However, by failing to recognize the individual and collective interests of both human and nonhuman animals - means that we are ensuring that none is effectively realized.

Therefore, by recognizing the fundamental link between these interests - and that suffering of and injustice to one - is suffering of and injustice to the other - the true notion of justice for all may finally become a reality. We can then appreciate that human rights are not impoverished, but rather enriched by expanding our scope of protection.

I believe that by utilizing this holistic approach in the field of animal law in South Africa, it will ensure it gains the support, traction and legitimacy it deserves. Only then will South Africa truly belong to all who live in it, and will we live up to constitutional promises of protection for all present, and future generations.

\section{Bibliography}

- African Union Website: https://au.int/memberstates. [Last Consultation Date: December 9 2018].

- AfricanLII Website: https://africanlii.org/blogs/andrewrens/feedback-loop-law-version-10 [Last Consultation Date: December 10 2018].

- Animal Enterprises Terrorism Act, see the Civil Liberties Defense Center Website: https://cldc.org/animal-enterprise-terrorism-act-aeta/ [Last Consultation Date: December 11 2018].

- Animal Legal Defense Fund's explanation. ALDF Website: https://aldf.org/issue/ag-gag/. [Last Consultation Date: December 92018$].$

- Animal Protection Act 71 of 1962 as amended. Animal Law Info Website: https://www.animallaw.info/sites/default/files/AnimalsProtectionAct71-62.pdf [Last Consultation Date: December 10 2018].

- Animal Protection Amendment Act Parliament Website: https://www.parliament.gov.za/storage/app/media/Docs/bill/74740ec4-a141-4451-90baebc6a1f0f415.pdf [Last Consultation Date: December 12 2018].

- Beauty Without Cruelty: Upon Receipt of a Petition From Beauty Without Cruelty and 84 Animal Rights NGOs. Message of Support From Prince Mangosuthu Buthelezi MP President Of The Inkatha Freedom Party http://www.ifp.org.za/newsroom/beauty-without-cruelty/ [Last Consultation Date: December 15 2018].

- BILCHITZ D. Exploring the Relationship between the Environmental Right in the South African Constitution and Protection for the Interests of Animals South African Law Journal 34 (2017) 740 777. (http://dx.doi.org/10.2139/ssrn.2942112). [Last Consultation Date: December 10 2018].

- BILCHITZ D. Moving Beyond Arbitrariness: The Legal Personhood and Dignity of Non-Human Animals' South African Journal on Human Rights 25 (2009) 38-72 (https://doi.org/10.1080/19962126.2009.11865192). [Last Consultation Date: December 10 2018].

- BILCHITZ D. What was Left Unsaid: The Unconstitutionality of the Performing Animals Protect Act in NSPCA v Minister of Agriculture, Forestry and Fisheries' South African Journal on Human Rights, 30 (2014) (https://hdl.handle.net/10520/EJC153000) [Last Consultation Date: December 14 2018].

- BILCHITZ D. When is Animal Suffering Necessary? (2012) Southern African Public Law, 27 (2012) 3-27. (https://journals.co.za/content/sapr1/27/1/EJC153188). [Last Consultation Date: December 12 2018].

- Biodiversity Finance Initiative Website: https://www.biodiversityfinance.net/south-africa [Last Consultation Date: December 13 2018].

- Biowatch Trust v Registrar Genetic Resources and Others (CCT 80/08) [2009] ZACC 14; 2009 (6) SA 232 (CC); 2009 (10) BCLR 1014 (CC) (3 June 2009). Saflii Website: http://www.saflii.org/za/cases/ZACC/2009/14.html. [Last Consultation Date: December 12 2018].

- BRANDT, F \& SPIERENBURG, M Game Fences in the Karoo: Reconfiguring Spatial and Social Relations Journal Of Contemporary African Society (2014) 1-18 (https://doi.org/10.1080/02589001.2014.925300) [Last Consultation Date: December 12 2018].

- Britannica Website: https://www.britannica.com/topic/Coloured. [Last Consultation Date: December 12 2018].

- CACH UK \& SPOTS Captive Lion Breeding, Canned Lion Hunting \& the Lion Bone Trade: Damaging Brand South Africa? A review of the worldwide reaction to South Africa's captive lion breeding and canned hunting industry and involvement in the lion bone trade Netherlands, August 2018 https://conservationaction.co.za/wp-content/uploads/2018/08/CACH-Brand-SA-ReviewAugust-2018.pdf. [Last Consultation Date: December 9 2018]. 
- Cape Chameleon Website: The Water Footprint of What We Eat https://capechameleon.co.za/thewater-footprint-of-what-we-eat/. [Last Consultation Date: December 12 2018].

- Center for Environmental Rights \& Endangered Wildlife Trust: Fair Game. CER Website: https://cer.org.za/wp-content/uploads/2018/06/CER-EWT-Regulation-of-Wildlife-Welfare-Report25-June-2018.pdf. [Last Consultation Date: December 13 2018]/

- Centers for Disease Control and Prevention Website: https://www.cdc.gov/globalhealth/countries/southafrica/what/one health.htm. [Last Consultation Date: December 13 2018].

- CITES Appendices. CITES Website: https://www.cites.org/eng/app/appendices.php. [Last Consultation Date: December 92018$].$

- CLAW. Website: http://www.claw-sa.org/about.html. [Last Consultation Date: December 11 2018].

- Conservation Action Trust. Website: Failure To Prosecute And Mixed Messages: How South Africa can single-handedly lose the second rhino war - Report: https://conservationaction.co.za/resources/reports/failure-prosecute-mixed-messages-south-africa-cansingle-handedly-lose-second-rhino-war/. [Last Consultation Date: December 13 2018].

- Constitution of the Republic of South Africa, 1996 (referred to as the Constitution). Government Website: http://www.justice.gov.za/legislation/constitution/SAConstitution-web-eng.pdf [Last Consultation Date: December 16 2018].

- Constitutional Court of South Africa Website: https://www.concourt.org.za/index.php/constitution/what-is-a-constitution. [Last Consultation Date: December 10 2018].

- Convention on Biological Diversity Website: https://www.cbd.int/. [Last Consultation Date: December 9 2018].

- Department of Agriculture, Forestries and Fisheries Website: https://www.daff.gov.za/Daffweb3/Portals/0/Statistics\%20and\%20Economic\%20Analysis/Statistical \%20Information/Abstract\%202018.pdf). [Last Consultation Date: December 11 2018].

- Department of Agriculture, Forestries and Fisheries Website: https://www.daff.gov.za/doadev/sidemenu/links/legislation.htm). [Last Consultation Date: December $132018]$.

- Department of Environmental Affairs Website: https://www.environment.gov.za/sites/default/files/gazetted_notices/nemba_elephantsinsa_g30833go n251.pdf. [Last Consultation Date: December 13 2018]. Other examples include the "Norms and Standards for the Management of Damage-causing Animals".

- Derebus Website: http://www.derebus.org.za/clarity-pro-bono-legal-practice-act/ [Last Consultation Date: December 11 2018].

- Derebus Website: http://www.derebus.org.za/litigation-costs-in-constitutional-matters/. [Last Consultation Date: December 10 2018].

- Docdroid Website: https://www.docdroid.net/0CAt7Nu/case86515-17-nspca-lionbones.pdf. [Last Consultation Date: December 13 2018].

- DUNSTAN M. The reform of the costs regime in South Africa: Part 2. Paper delivered at the Middle Temple and SA Conference by Justice Dunstan Mlambo, Judge President of the South and North Gauteng High Courts https://www.sabar.co.za/law-journals/2012/august/2012-august-vol025-no2pp22-33.pdf. [Last Consultation Date: December 10 2018].

- Game Theft Act 105 of 1991. South African Police Services Website: https://www.saps.gov.za/resource centre/acts/downloads/juta/news1334.pdf [Last Consultation Date: December 10 2018].

- GRIFFITHS, M. Heritage lost: The cultural impact of wildlife crime in South Africa, SA Crime Quarterly (2017) 45-50. (http://dx.doi.org/10.17159/2413-3108/2017/v0n60a1728) [Last Consultation Date: December 11 2018].

- HORSTHEMKE K. Animal Rights Education The Palgrave Macmillan Animal Ethics Series: ISBN 978-3-319-98592-3 ISBN 978-3-319-98593-0 (eBook): (https://doi.org/10.1007/978-3-319-98593-0). [Last Consultation Date: December 13 2018].

- HÜBSCHLE, A. A Game of Horns: Transnational Flows of Rhino Horn (2016) ISBN: I978-3946416-12-8, (DOI: 10.17617/2.2218357). [Last Consultation Date: December 132018 ].

- Kruger and Another v Minister of Water and Environmental Affairs and Others (57221/12) [2015] ZAGPPHC 1018; [2016] 1 All SA 565 (GP) (28 November 2015). Saflii Website: http://www1.saflii.org/cgi-bin/disp.pl?file=za/cases/ZAGPPHC/2015/1018.html\&query=hume. [Last Consultation Date: December 132018$].$ 
- Legal

Practice

Act: https://www.lssa.org.za/upload/documents/Legal\%20Practice\%20Act $\% 20 \mathrm{GG} \% 2038022 \% 20$ of $\% 202$ 2\%20September\%202014.pdf [Last Consultation Date: December 11 2018].

- Lemthongthai v S (849/2013) [2014] ZASCA 131; 2015 (1) SACR 353 (SCA) (25 September 2014). Saflii Website: http://www.saflii.org/za/cases/ZASCA/2014/131.html. [Last Consultation Date: December 13 2018].

- Listeria Class Action Website: https://listeriaclassaction.co.za/.[Last Consultation Date: December 12 2018].

- Livestock Welfare Coordinating Committee Website: http://wwcc.org.za/. [Last Consultation Date: December 9 2018].

- MEYERSFELD, B. Non-Human Animals and the Law: The Fable of Power South African Public Law Journal (2012-2013).

- Minister of Agriculture, Forestry and Fisheries v National Society for the Prevention of Cruelty to Animals (CCT186/16) [2016] ZACC 26; 2016 (11) BCLR 1419 (CC) (25 August 2016). Saflii Website: http://www.saflii.org/za/cases/ZACC/2016/26.html [Last Consultation: December 13 2018].

- MKHIZE, N. Game Farm Conversions and the Land Question: Unpacking Present Contradictions and Historical Continuities in Farm Dwellers' Tenure Insecurity in Cradock Journal Of Contemporary African Society 32 (2014) 207-219 (https://doi.org/10.1080/09637494.2014.937164) [Last Consultation Date: December 9 2018].

- MQINGWANA, B. An analysis of locus standi in public interest litigation with specific reference to environmental law: a comparative study between the law of South Africa and the law of the United States of America. Pretoria University Repository Website: https://repository.up.ac.za/handle/2263/27926. [Last Consultation Date: December 112018 ]

- MUBANGIZI, JC \& MBAZIRA C, Constructing the Amicus Curiae procedure in human rights litigation: What can Uganda learn from South Africa?, Law Democracy and Development 16 (2012) (http://dx.doi.org/10.4314/ldd.v16i1.11) [Last Consultation Date: December 9 2018].

- National Council of Societies for the Prevention of Cruelty to Animals v Openshaw (462/07) [2008] ZASCA 78; [2008] 4 All SA 225 (SCA); 2008 (5) SA 339 (SCA) (30 May 2008). Saflii Website: http://www.saflii.org/za/cases/ZASCA/2008/78.html. [Last Consultation Date: December 13 2018].

- National Environmental Management Act, 107 of 1998 (NEMA). Ecolex Website: https://www.ecolex.org/details/legislation/national-environmental-management-act-1998-no-107-of1998-lex-faoc018752/. [Last Consultation Date: December 13 2018].

- National Environmental Management: Biodiversity Act, 10 of 2004 (NEMBA). National Department of Agriculture Website: https://www.nda.agric.za/docs/NPPOZA/NEMBA.pdf. [Last Consultation Date: December 13 2018].

- National Society for the Prevention of Cruelty to Animals v Minister of Justice and Constitutional Development and Another (CCT1/16) [2016] ZACC 46; 2017 (1) SACR 284 (CC); 2017 (4) BCLR
517
(CC)
(8) December
2016).
Saflii
Website:

http://www.saflii.org/za/cases/ZACC/2016/46.html\# ftn91

- NSPCA Website: https://nspca.co.za/wp-content/uploads/2016/05/Abuse.pdf. [Last Consultation Date: December 9 2018]. ASCIONE, F. Animal Abuse and Youth Violence. U.S. Department of Justice Website: https://www.ncjrs.gov/pdffiles1/ojjdp/188677.pdf. [Last Consultation Date: December 112018$]$.

- NSPCA Website: https://nspca.co.za/wp-content/uploads/2016/05/Animal-Protections.pdfv). [Last Consultation Date: December 12 2018]

- NYENTI, M, Access to justice in the South African social security: Towards a conceptual approach" Dejure 44 (2013). Saflii Website: http://www.saflii.org/za/journals/DEJURE/2013/44.html [Last Consultation Date: December 14 2018].

- Parliamentary Portfolio Committee on Environmental Affairs (PCEA) adopted a 24-page report on Captive Lion Breeding for Hunting and Bone Trade in South Africa: EMS Foundation Website: https://emsfoundation.org.za/wp-content/uploads/Report-of-the-Portfolio-Committee-onEnvironmental-Affairs.pdf [Last Consultation Date: December 14 2018].

- Promotion of Administration to Justice Act. Government Website: http://www.justice.gov.za/legislation/acts/2000-003.pdf [Last Consultation Date: December 10 2018].

- RONQUEST-ROSS L-C, VINK N, SIGGE GO. Food consumption changes in South Africa since 1994. South African Journal of Science (2015) 111. (http://dx.doi.org/10.17159/ sajs.2015/20140354). [Last Consultation Date: December 13 2018] 
- SA History Website: https://www.sahistory.org.za/article/customary-law-south-africa-historicaldevelopment-legal-system-and-its-relation-women $\% \mathrm{E} 2 \% 80 \% 99 \mathrm{~s}-$ righ $\quad$ [Last Consultation Date: December 10 2018]. Customary law has also been formally adopted into legislation, such as the Recognition of Customary Marriages Act 120 of 1998. Government Website: http://www.justice.gov.za/legislation/acts/1998-120.pdf [Last Consultation Date: December 102018$]$

- SA Predator Breeders Association and Others v Minister of Environmental Affairs and Tourism (72/10) [2010] ZASCA 151; [2011] 2 All SA 529 (SCA) (29 November 2010). Saflii Website: http://www.saflii.org/za/cases/ZASCA/2010/151.html. [Last Consultation Date: December 13 2018].

- Smit NO and Others v King Goodwill Zwelithini Kabhekuzulu and Others (10237/2009) [2009] ZAKZPHC $\quad 75$ (4 December 2009). Saflii Website: http://www.saflii.org/za/cases/ZAKZPHC/2009/75.html. [Last Consultation Date: December 12 2018]

- Societies for the Prevention of Cruelty to Animals Act 169 of 1993. Saflii Website: http://www.saflii.org/za/legis/num act/sftpoctaa1993521/. [Last Consultation Date: December 14 2018]

- SPIERENBURGAB M \& BROOKS S. Private game farming and its social consequences in postapartheid South Africa: contestations over wildlife, property and agrarian futures, Journal of Contemporary African Studies 32 (2014) http://www.tandfonline.com/loi/cjca20. [Last Consultation Date: December 11 2018].

- Statistics SA Website: $h \mathrm{http}: / / w w w . s t a t s s a . g o v . z a / p u b l i c a t i o n s / P 0341 / P 03412018 . p d f$. [Last Consultation Date: December 9 2018].

- Supreme Court of South Africa: Website: http://www.justice.gov.za/sca/historysca.htm [Last Consultation Date: December 112018$]$

- The Performing Animals Protection Act 24 of 1935. Government Website: https://www.gov.za/documents/performing-animals-protection-amendment-act-4-2016-englishafrikaans-19-jan-2017-0000 [Last Consultation Date: December 10 2018]

- Threatened or Protected Species Regulations, 2007. Department of Environmental Affairs Website: https://www.environment.gov.za/sites/default/files/legislations/nemba threatenedspecies regulations g29657rg8638gon152.pdf. [Last Consultation Date: December 13 2018]

- TISCHLER.J, The History of Animal Law, Part I (1972-1987) Stanford Journal of Animal Law \& Policy $\begin{array}{lllll}1 & 1 & \text { (2008) } & \text { https://law.stanford.edu/wp-content/uploads/2018/05/tischler-1.pdf } \\ \text { [Last }\end{array}$ Consultation Date: December 14 2018] and

- TISCHLER.J A Brief History of Animal Law, Part II (1985 - 2011) Stanford Journal of Animal Law \& Policy 5 (2012) https://www.animallaw.info/sites/default/files/tischler2012.pdf. [Last Consultation Date: December 14 2018]

- United Nation's International Convention on the Suppression and Punishment of the Crime of Apartheid. Adopted by the General Assembly of the United Nations on 30 November 1973. Website: https://treaties.un.org/doc/Publication/UNTS/Volume\%201015/volume-1015-I-14861-English.pdf [Last Consultation Date: December 142018$]$

- University of KwaZulu-Natal Website: the Prohibition of Mixed Marriages Act 55 of 1949, Natives Laws Amendment Act of 1952 and various others. http://scnc.ukzn.ac.za/doc/HIST/Apartheid\%20Legislation\%20in\%20South\%20Africa.htm [Last Consultation Date: December 13 2018].

- Universal Declaration of Animal Welfare. World Animal Protection Website: http://www.wspausa.org/wspaswork/udaw/. [Last Consultation Date: December 9 2018]

- VAN DEN HONERT, M. S.; GOUWS, P. A. and HOFFMAN, L. C. Importance and implications of antibiotic resistance development in livestock and wildlife farming in South Africa: A Review. South African Journal of Animal Science 48 (2018) 401-412 (http://dx.doi.org/10.4314/sajas.v48i3.1) [Last Consultation Date: December 13 2018]

- VICTOR K \& BARNARD A. Slaughtering for a living: A hermeneutic phenomenological perspective on the well-being of slaughterhouse employees International Journal of Qualitative Studies on Health and Well-being (2016) 11:30266. (doi:10.3402/qhw.v11.30266)

- VICTOR K AND BARNARD A Post-traumatic stress of employees working as slaughterers' UNISA University,

http://uir.unisa.ac.za/bitstream/handle/10500/18454/PTSD\%20Slaughtering\%20Poster\%20A\%20Barn ard\%202003.pdf?sequence $=1$ [Last Consultation Date: December 9 2018]

- World Animal Net Website: http://worldanimal.net/images/stories/documents/Africa/AWSA.pdf. [Last Consultation Date: December 92018$]$ 
- World Organization for Animal Health Website: http://www.oie.int/. Standards for animals: http://www.oie.int/animal-welfare/oie-standards-and-international-trade. [Last Consultation Date: December 92018$]$

- YOUENS, K. Animal Rights A Moral And Legal Discussion On The Standing Of Animals In South African Law. Youens Attorneys Website: https://youensattorneys.co.za/wpcontent/uploads/2016/08/animal-rights.pdf. [Last Consultation Date: December 92018 ]. 